\title{
Supramolecular Vesicles Based on Complex of Trp-modified Pillar[5]arene and Galactose Derivative for Synergistic and Targeted Drug Delivery
}

Kui Yang, Yincheng Chang, Jia Wen, Yuchao Lu, Yuxin Pei,* Shoupeng Cao, Feng Wang, and Zhichao Pei*

College of Science, Northwest A\&F University, Yangling, Shaanxi 712100, People's Republic of China

\section{Supporting Information (pages)}

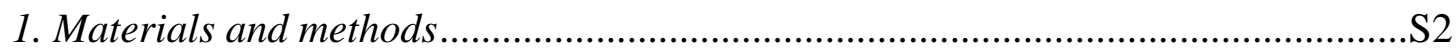

2. Synthesis and characterization of the compounds ...................................................

3. NMR and UV-Vis studies of host-guest complexation of $\boldsymbol{G}$ and $\mathbf{T P 5}$...................S14

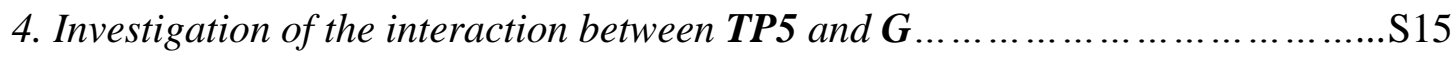

5. The preparation and characterization of the vesicles.......................................S177

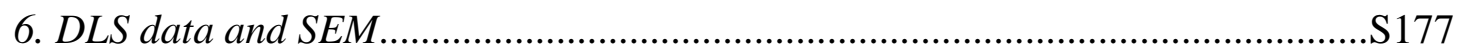

7. Critical aggregation concentration (CAC) determination of TP5 .....................S188

8. Electrophoretic mobility and UV-Vis studies of the interaction between TP5 and

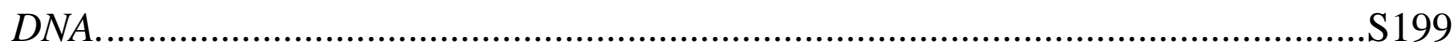

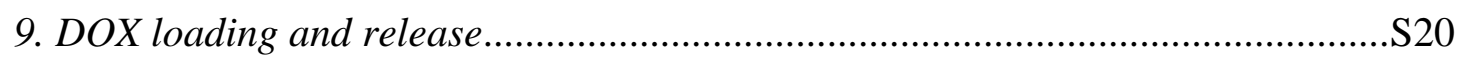

10. The study of targeting effect by flow cytometry ................................................. 21

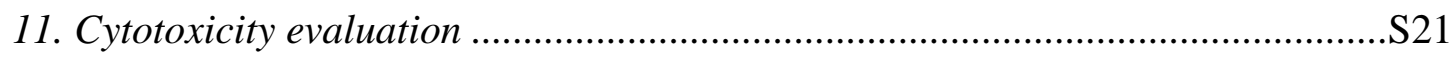

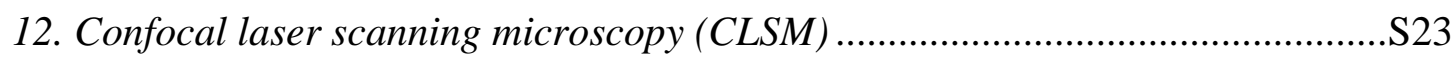

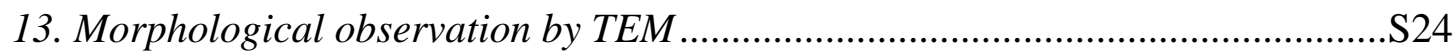

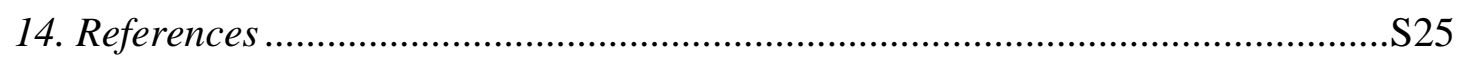




\section{Materials and methods}

All reagents were purchased from commercial suppliers and used without further purification unless specified. Water used in this work was triple distilled. Doxorubicin hydrochloride (DOX) was purchased from Sangon Biotech. DNA sodium salt for salmon testes was purchased from Aladdin Reagents Company. $\mathrm{N}$-[(tert-Butoxy)carbonyl]-L-tryptophan (Boc-Trp-OH), N, N-Diisopropylethylamine (DIPEA) and 4-Dimethylaminopyridine (DMAP) were purchased from Energy Chemical Reagent Co.. 1-(3-Dimethylaminopropyl)-3-ethylcarbodiimide hydrochloride $(\mathrm{EDC} \cdot \mathrm{HCl})$ was purchased from Jiu Ding Chemistry Reagent Co.. NMR spectra were recorded on a Bruker $500 \mathrm{MHz}$ Spectrometer with working frequencies of $500 \mathrm{MHz}$ for ${ }^{1} \mathrm{H}$ and $125 \mathrm{MHz}$ for ${ }^{13} \mathrm{C}$, respectively. An AXIMA-CFR ${ }^{\mathrm{TM}}$ plus MALDI-TOF Mass Spectrometer (Kratos, UK) was used for mass analysis. SEM images were obtained using an S-4800 instrument (Hitachi Ltd.) with an accelerating voltage of $10.0 \mathrm{kV}$. Negative-stained TEM images were recorded on an H-7650 instrument (Hitachi Ltd. $80 \mathrm{kV}$ ). DLS measurements were performed on a DelsaTM Nano system (Beckman Coulter). UV-Vis spectra were recorded with a Shimadzu 1750 UV-visible spectrophotometer (Japan) at $298 \mathrm{~K}$. Cell culture was carried out in an incubator with a humidified atmosphere of $5 \% \mathrm{CO}_{2}$ at $37{ }^{\circ} \mathrm{C}$. 


\section{Synthesis and characterization of the compounds}

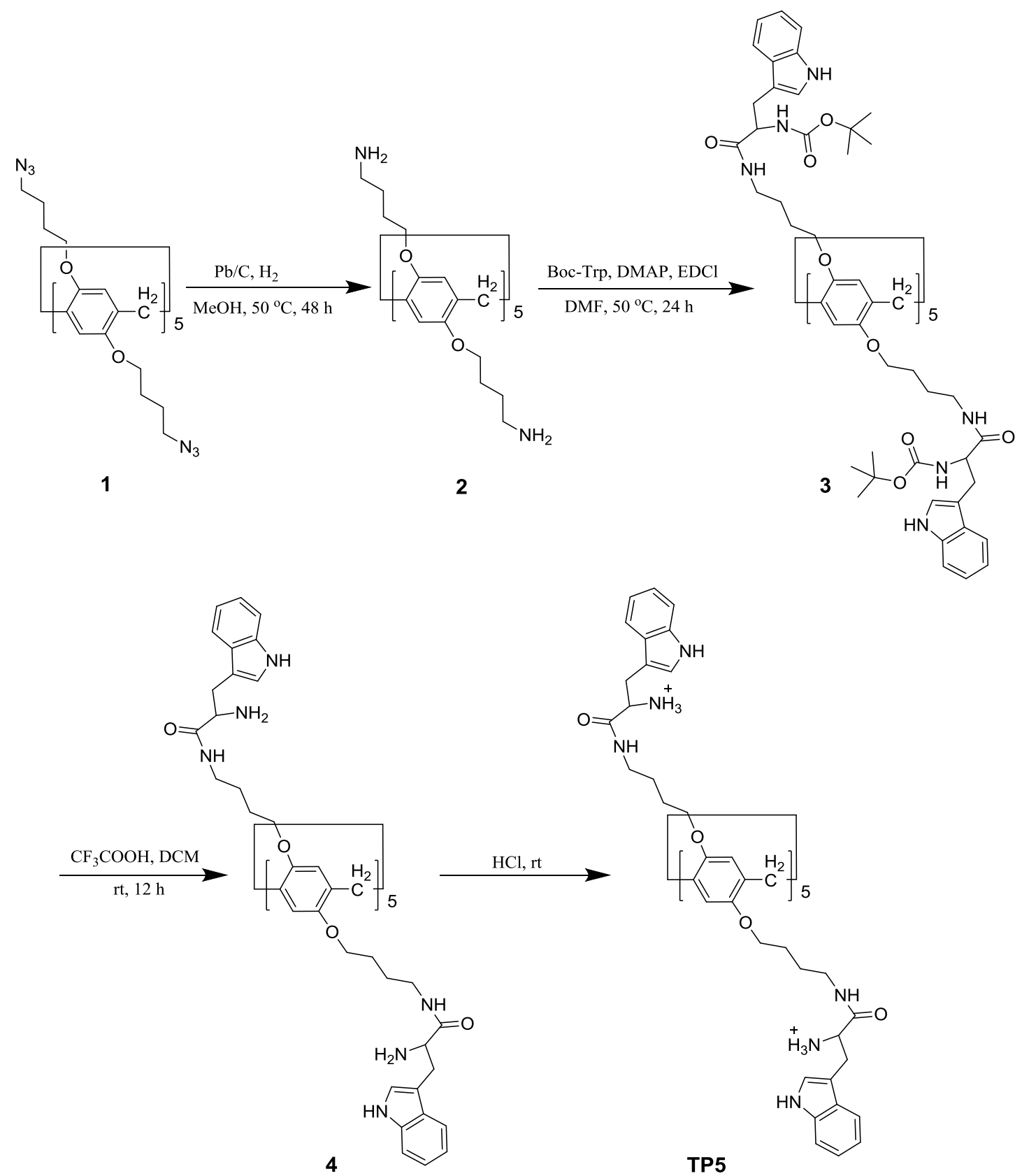

Scheme S1. Synthetic route of TP5.

Compound 2: A mixture of $\mathbf{1}^{\mathrm{S} 1}(158 \mathrm{mg}, 0.10 \mathrm{mmol})$ and $\mathrm{Pb} / \mathrm{C}(10 \%, 25 \mathrm{mg})$ in $5 \mathrm{~mL}$ $\mathrm{CH}_{3} \mathrm{OH}$ was stirred at $50{ }^{\circ} \mathrm{C}$ under hydrogen atmosphere (100 psi) for $48 \mathrm{~h}$. The resulting mixture was filtered, and the filtrate was concentrated under reduced pressure to give 2 as a white solid (120 mg, $92 \%)$. ${ }^{1} \mathrm{H}$ NMR (500 MHz, MeOD, ppm): $\delta 6.85(\mathrm{~s}, 10 \mathrm{H}), 3.87(\mathrm{t}, J=5.7 \mathrm{~Hz}, 20 \mathrm{H}), 3.74(\mathrm{~s}, 10 \mathrm{H}), 2.60(\mathrm{t}, J=7.1 \mathrm{~Hz}, 20 \mathrm{H})$, $1.87-1.79(\mathrm{~m}, 20 \mathrm{H}), 1.72-1.55(\mathrm{~m}, 20 \mathrm{H}) .{ }^{13} \mathrm{C}$ NMR (125 MHz, DMSO- $\left.d_{6}, \mathrm{ppm}\right): \delta$ 149.6, 128.3, 114.5, 68.4, 55.4, 42.1, 30.5, 27.4. MALDI-TOF-MS: $\mathrm{m} / \mathrm{z}$ calcd for $[M$ 
$+\mathrm{H}]^{+} \mathrm{C}_{75} \mathrm{H}_{121} \mathrm{~N}_{10} \mathrm{O}_{10}{ }^{+}, 1321.9262$, found 1321.3387.
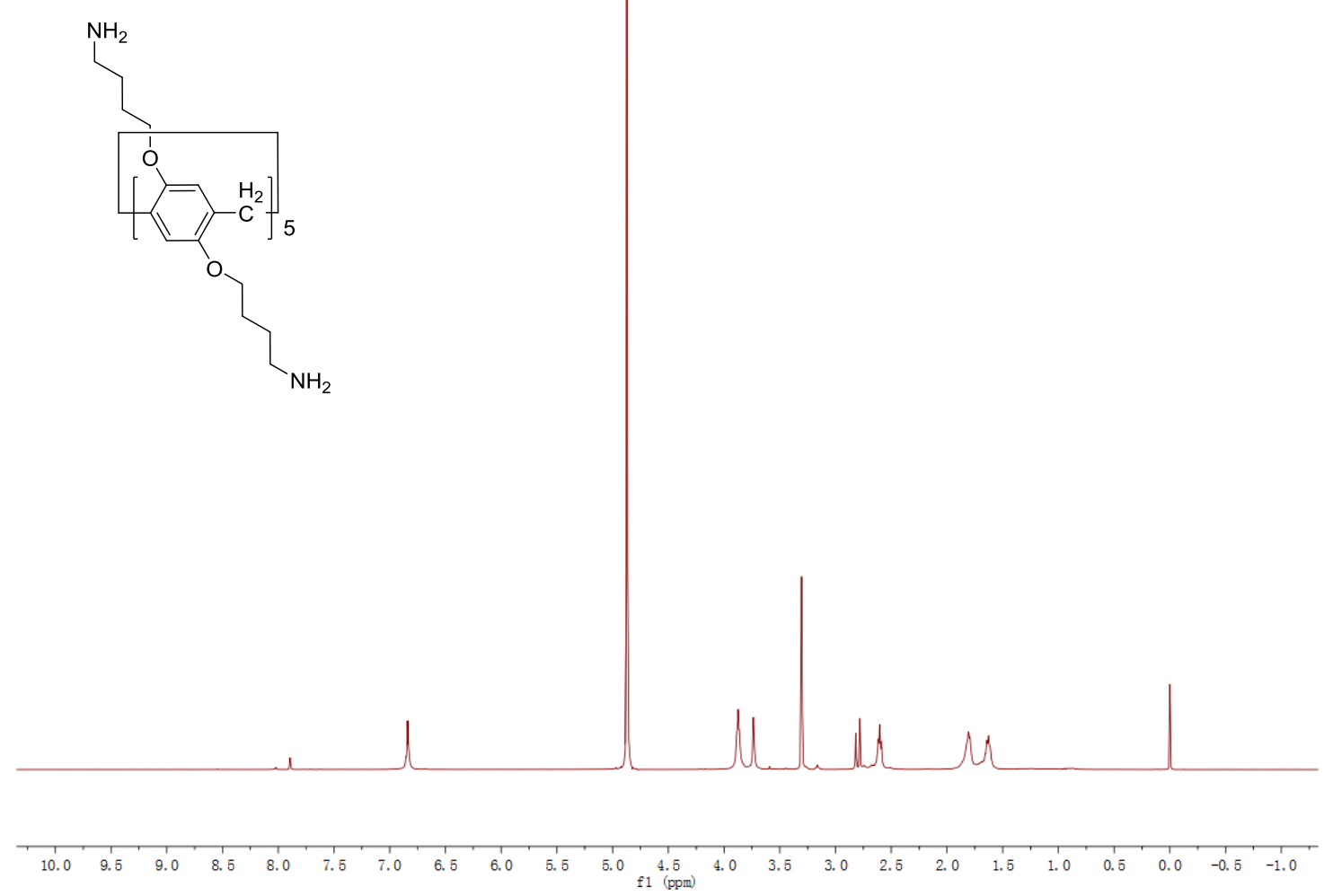

Figure S1. ${ }^{1} \mathrm{H}$ NMR spectrum (500 MHz, MeOD) of 2.
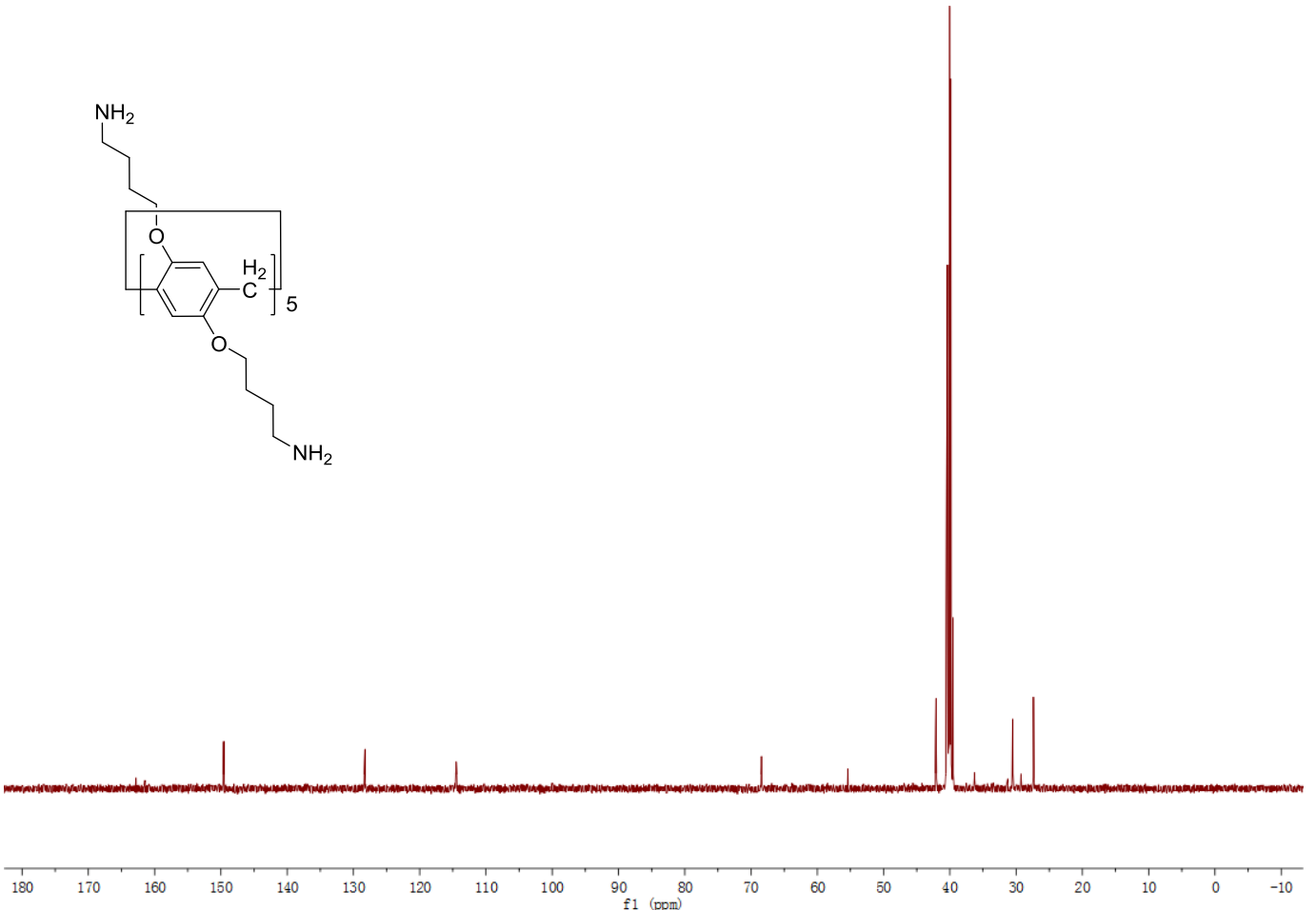

Figure S2. ${ }^{13} \mathrm{C}$ NMR spectrum $\left(125 \mathrm{MHz}, \mathrm{DMSO}-d_{6}\right)$ of 2. 
Compound 3: A mixture of 2 (93.8 mg, $0.07 \mathrm{mmol})$, Boc-Trp-OH (319.2 mg, 1.05 mmol), DMAP (512.4 mg, $4.2 \mathrm{mmol})$ and $\mathrm{EDC} \cdot \mathrm{HCl}(200.6 \mathrm{mg}, 1.05 \mathrm{mmol})$ in $10 \mathrm{~mL}$ DMF was stirred at $50{ }^{\circ} \mathrm{C}$ for $24 \mathrm{~h}$, then $20 \mathrm{~mL}$ DCM was added into the mixture. The mixture was washed with water $(2 \times 20 \mathrm{~mL})$, saturated $\mathrm{NaCl}(2 \times 20 \mathrm{~mL})$ and $1 \mathrm{M}$ $\mathrm{HCl}(2 \times 20 \mathrm{~mL})$. The organic phase was dried with $\mathrm{MgSO}_{4}$ and concentrated under reduced pressure. The crude product was purified by flash column chromatography (eluent: $\left.\mathrm{DCM} / \mathrm{CH}_{3} \mathrm{OH}=50: 1\right)$ to give 3 as a white solid $(87.8 \mathrm{mg}, 30 \%)$. ${ }^{1} \mathrm{H} \mathrm{NMR}$ (500 MHz, DMSO- $\left.d_{6}, \mathrm{ppm}\right): \delta 10.80(\mathrm{~s}, 10 \mathrm{H}), 7.98(\mathrm{~s}, 10 \mathrm{H}), 7.58(\mathrm{~d}, J=7.6 \mathrm{~Hz}, 10$ H), $7.33(\mathrm{~d}, J=7.7 \mathrm{~Hz}, 10 \mathrm{H}), 7.13(\mathrm{~s}, 10 \mathrm{H}), 7.05(\mathrm{t}, J=7.4 \mathrm{~Hz}, 10 \mathrm{H}), 6.96(\mathrm{t}, J=$ $7.2 \mathrm{~Hz}, 10 \mathrm{H}), 6.84(\mathrm{~s}, 10 \mathrm{H}), 6.71(\mathrm{~d}, J=6.6 \mathrm{~Hz}, 10 \mathrm{H}), 4.23(\mathrm{~s}, 10 \mathrm{H}), 4.08-3.98(\mathrm{~m}$, $10 \mathrm{H}), 3.70(\mathrm{~d}, J=19.9 \mathrm{~Hz}, 20 \mathrm{H}), 3.19(\mathrm{~s}, 20 \mathrm{H}), 3.11-3.05(\mathrm{~m}, 10 \mathrm{H}), 3.01-2.87$ (m, $10 \mathrm{H}), 1.89-1.61(\mathrm{~m}, 40 \mathrm{H}), 1.40-1.06(\mathrm{~m}, 90 \mathrm{H}) .{ }^{13} \mathrm{C}$ NMR $\left(125 \mathrm{MHz}, \mathrm{DMSO}-d_{6}\right.$, ppm): $\delta 172.4,155.6,149.5,136.5,128.5,127.8,124.0,121.3,119.0,118.6,111.7$, $110.8,78.4,68.1,55.8,55.4,38.9,28.6,28.4,28.2,27.2,26.4$. MALDI-TOF-MS: $m / z$ calcd for $[M]^{+} \mathrm{C}_{235} \mathrm{H}_{300} \mathrm{~N}_{30} \mathrm{O}_{40}{ }^{+}, 4182.2363$, found 4182.8123 .

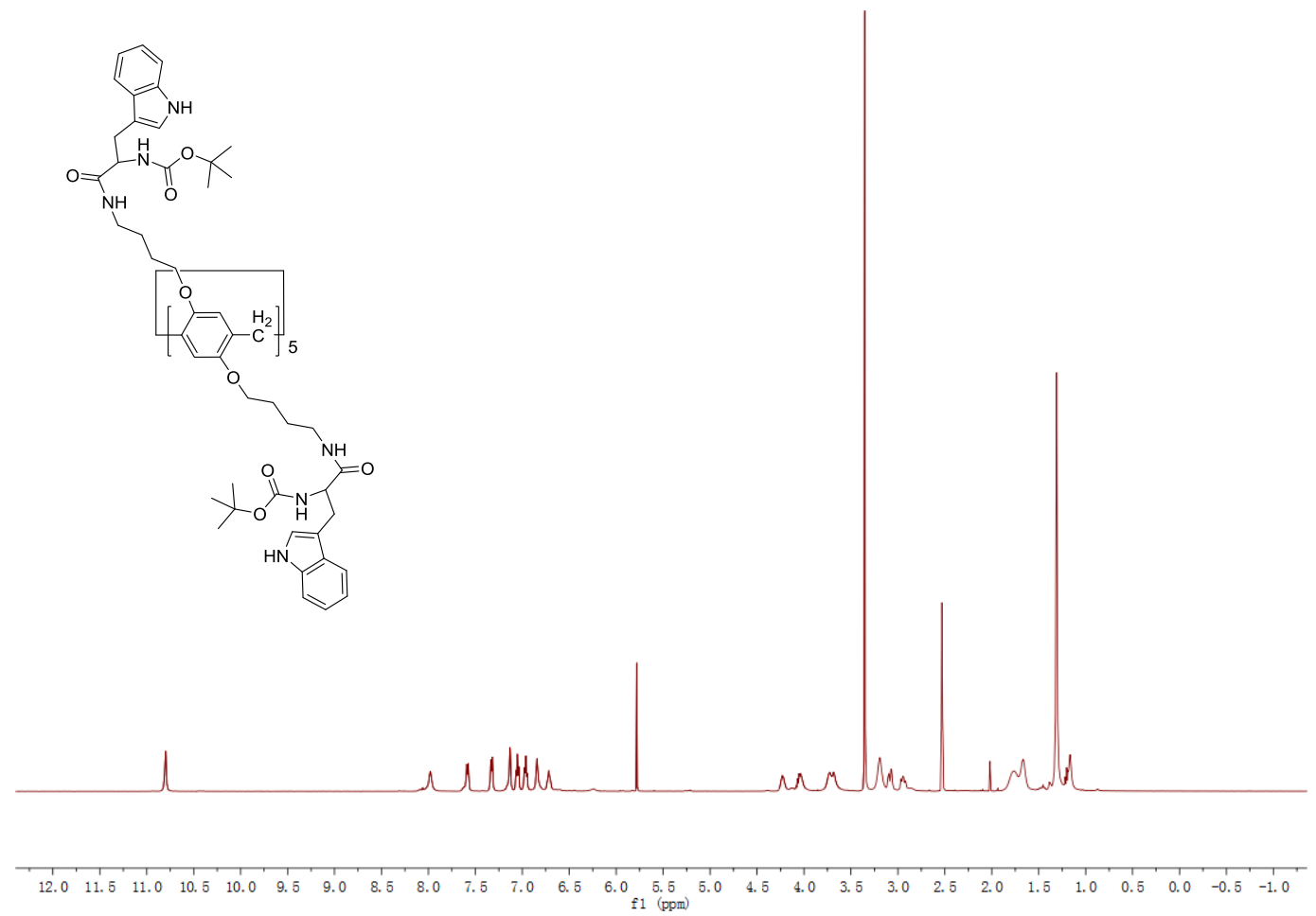

Figure S3. ${ }^{1} \mathrm{H}$ NMR spectrum (500 MHz, DMSO- $\left.d_{6}\right)$ of 3. 


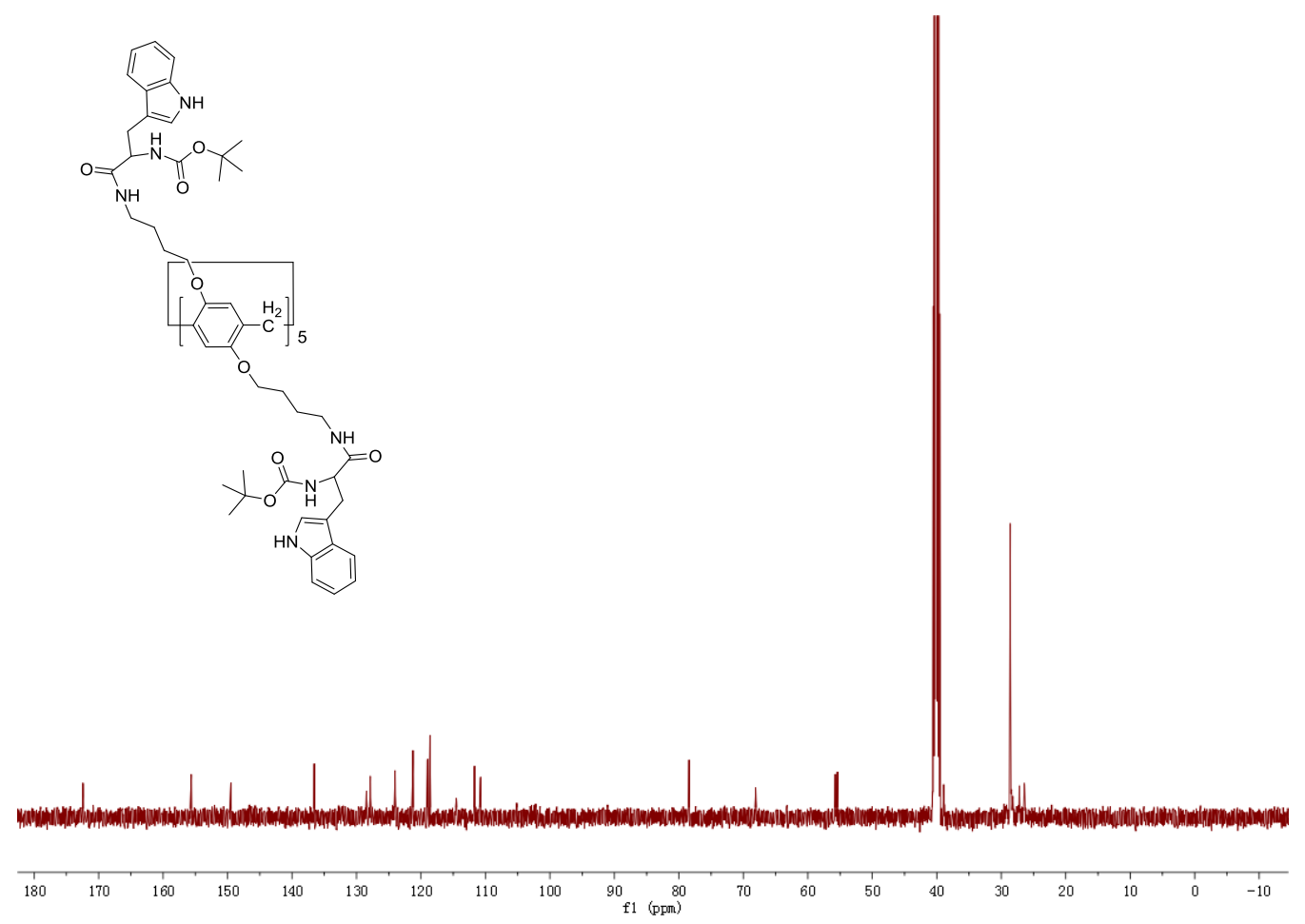

Figure S4. ${ }^{13} \mathrm{C}$ NMR spectrum $\left(125 \mathrm{MHz}, \mathrm{DMSO}-d_{6}\right)$ of $\mathbf{3}$.

Compound 4: $\mathrm{CF}_{3} \mathrm{COOH}(75 \mu \mathrm{L}, 1 \mathrm{mmol})$ was added into a solution of compound 3 (41.8 $\mathrm{mg}, 0.01 \mathrm{mmol}$ in $5 \mathrm{~mL} \mathrm{DCM}$ ) in ice-bath. The mixture was stirred at room temperature overnight, then concentrated under reduced pressure. The crude product was treated with saturated $\mathrm{NaHCO}_{3}$ solution. The white solid was collected and washed with water for 3 times to give 4 (30.2 mg, $95 \%)$. ${ }^{1} \mathrm{H}$ NMR (500 MHz, DMSO- $d_{6}$, ppm): $\delta 10.86(\mathrm{~s}, 10 \mathrm{H}), 7.96(\mathrm{~s}, 10 \mathrm{H}), 7.57$ (d, J = 7.8 Hz, $\left.10 \mathrm{H}\right), 7.34$ (d, $J=8.1 \mathrm{~Hz}, 10 \mathrm{H}), 7.16(\mathrm{~s}, 10 \mathrm{H}), 7.06(\mathrm{t}, J=7.1 \mathrm{~Hz}, 10 \mathrm{H}), 6.96(\mathrm{t}, J=7.1 \mathrm{~Hz}, 10 \mathrm{H})$, $6.85(\mathrm{~s}, 10 \mathrm{H}), 4.02(\mathrm{~s}, 10 \mathrm{H}), 3.80-3.65(\mathrm{~m}, 20 \mathrm{H}), 3.50-3.44(\mathrm{~m}, 10 \mathrm{H}), 3.21(\mathrm{~s}, 20 \mathrm{H})$, $3.11(\mathrm{dd}, J=14.1,4.2 \mathrm{~Hz}, 10 \mathrm{H}), 2 . .80-2.73(\mathrm{~m}, 10 \mathrm{H}), 1.75-1.65(\mathrm{~m}, 40 \mathrm{H}) .{ }^{13} \mathrm{C}$ NMR (125 MHz, DMSO- $\left.d_{6}, \mathrm{ppm}\right): \delta 175.2,149.6,136.8,128.3,128.0,124.1,121.3$, $119.0,118.7,114.7,111.8,111.3,79.7,68.2,56.0,38.8,31.8,27.3,26.6$. MALDI-TOF-MS: $m / z$ calcd for $[M+N a]^{+} \mathrm{C}_{185} \mathrm{H}_{220} \mathrm{~N}_{30} \mathrm{NaO}_{40}{ }^{+}, 3204.7012$, found 3204.4129 . 


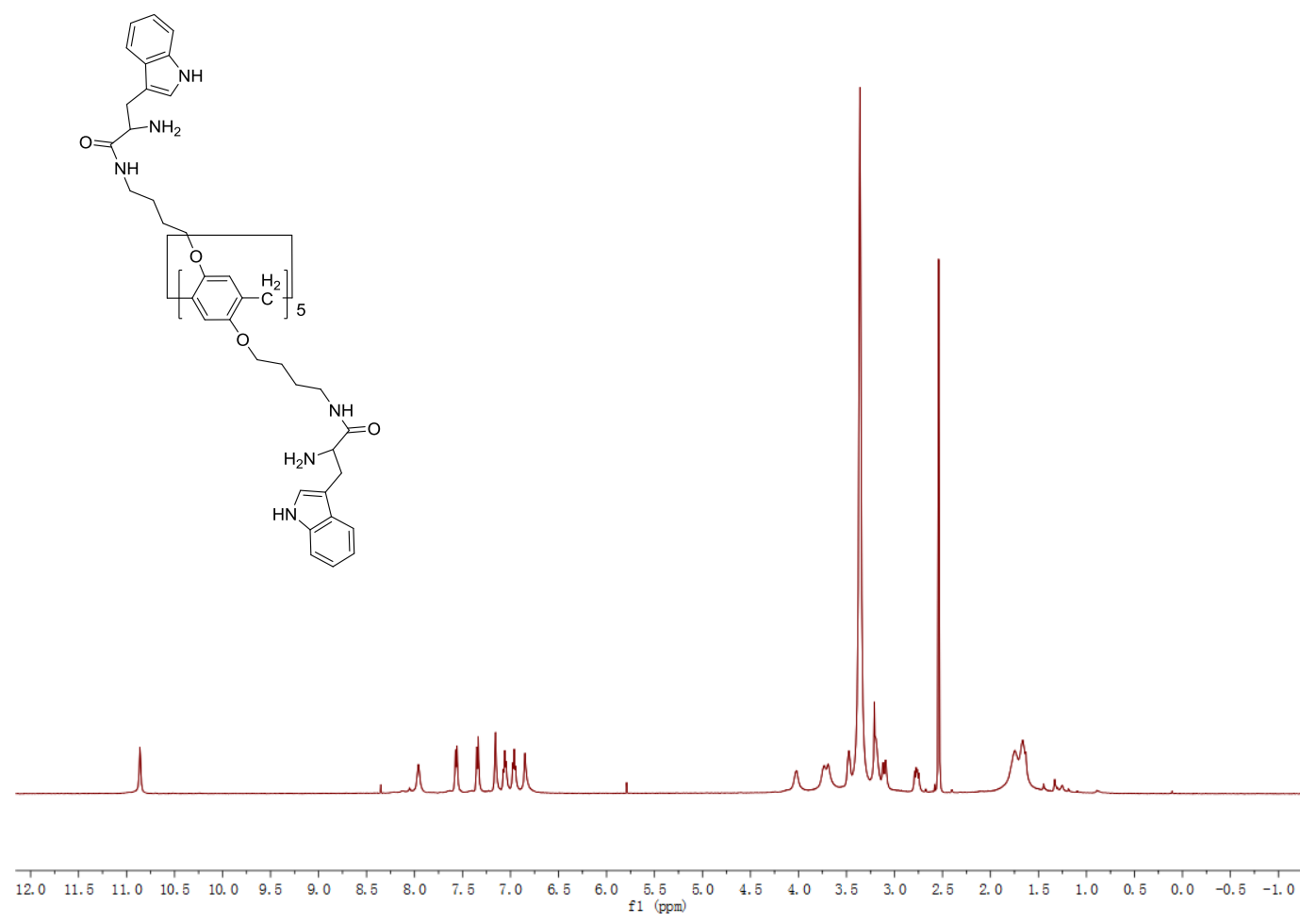

Figure S5. ${ }^{1} \mathrm{H}$ NMR spectrum (500 MHz, DMSO- $\left.d_{6}\right)$ of 4.

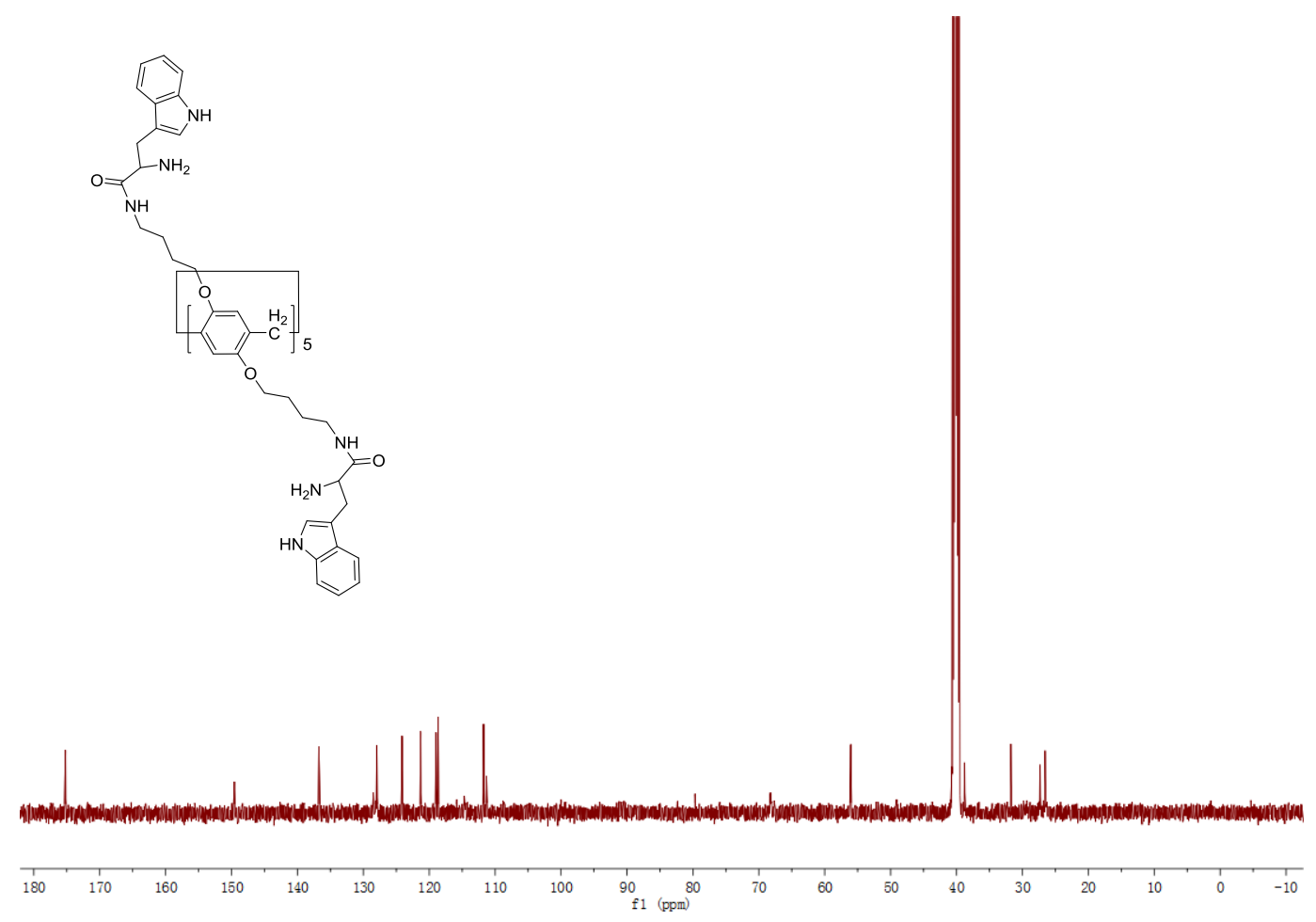

Figure S6. ${ }^{13} \mathrm{C}$ NMR spectrum $\left(125 \mathrm{MHz}, \mathrm{DMSO}-d_{6}\right)$ of 4. 


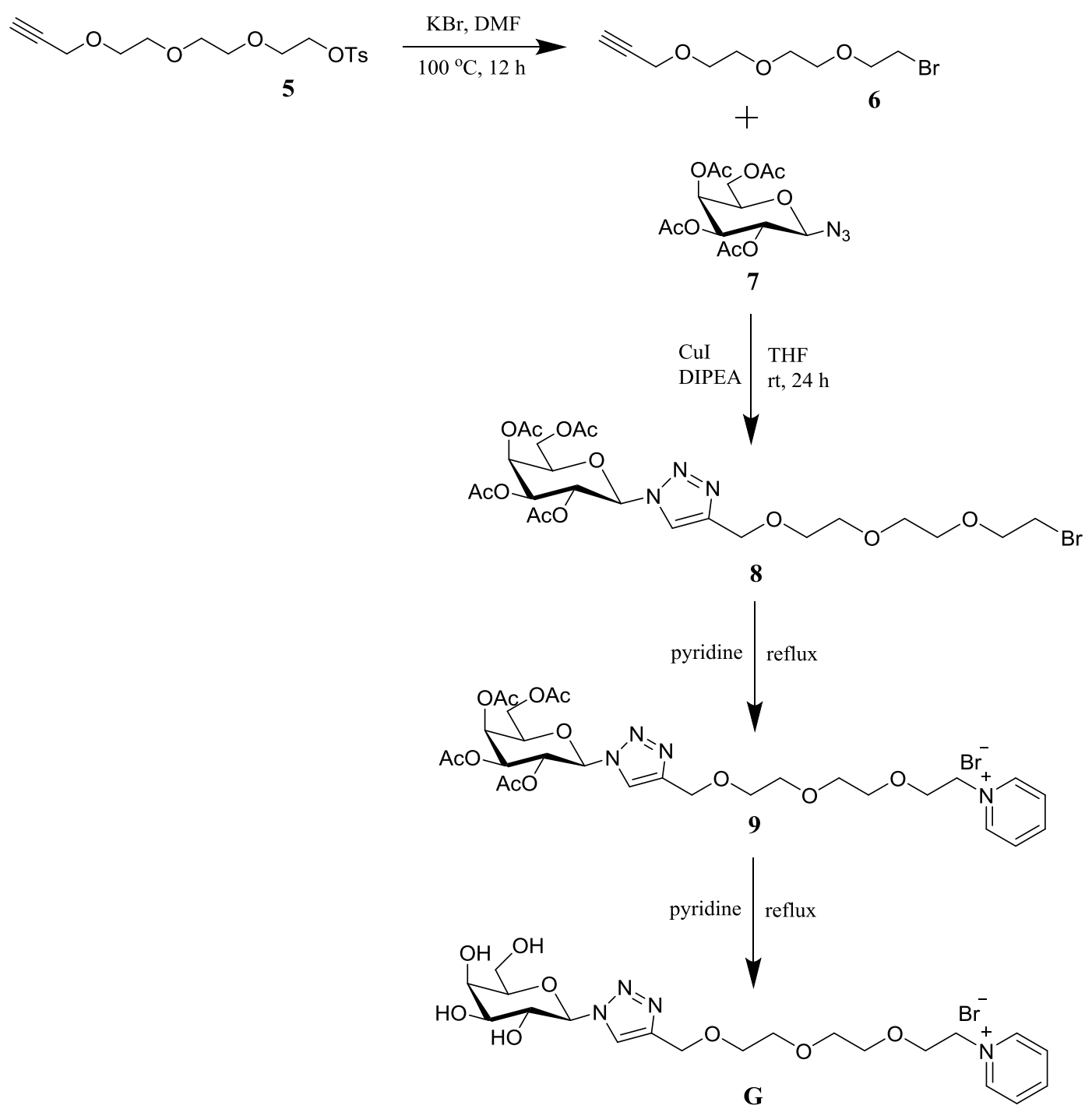

Scheme $\mathbf{S 2}$. Synthetic route of $\mathbf{G}$.

Compound 6: The synthesis of $\mathbf{5}$ was performed according to the previously published procedure $^{\mathrm{S} 2}$. A mixture of $5(3.4 \mathrm{~g}, 10 \mathrm{mmol})$ and $\mathrm{KBr}(5.9 \mathrm{~g}, 50 \mathrm{mmol})$ was dissolved in $30 \mathrm{~mL}$ DMF. The mixture was stirred at $100{ }^{\circ} \mathrm{C}$ for $12 \mathrm{~h}$. Then $100 \mathrm{~mL}$ DCM was added into the mixture. The mixture was washed with water $(3 \times 80 \mathrm{~mL})$ and saturated $\mathrm{NaCl}(3 \times 80 \mathrm{~mL})$. The organic phase was dried with $\mathrm{MgSO}_{4}$, then concentrated under reduced pressure. The crude product was isolated by flash column chromatography (eluent: petroleum ether/dichloromethane $=1: 1$ ) to give $\mathbf{6}$ as a yellow oil (1.5 g, $60 \%) .{ }^{1} \mathrm{H}$ NMR (500 MHz, $\left.\mathrm{CDCl}_{3}, \mathrm{ppm}\right): \delta 4.20$ (d, $\left.J=2.4 \mathrm{~Hz}, 2 \mathrm{H}\right), 3.83$ 
- 3.79 (m, $2 \mathrm{H}), 3.71-3.64(\mathrm{~m}, 8 \mathrm{H}), 3.49-3.44(\mathrm{~m}, 2 \mathrm{H}), 2.42(\mathrm{t}, \mathrm{J}=2.4 \mathrm{~Hz}, 1 \mathrm{H}) .{ }^{13} \mathrm{C}$ NMR (125 MHz, $\left.\mathrm{CDCl}_{3}, \mathrm{ppm}\right): \delta 79.7,74.6,71.2,70.7,70.6,70.5,69.1,58.5,30.3$.<smiles>C#CCOCCOCCOCCBr</smiles>
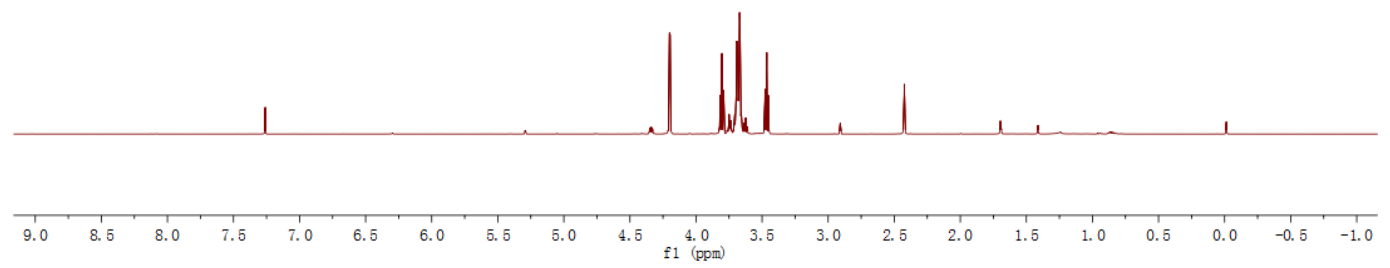

Figure S7. ${ }^{1} \mathrm{H} \mathrm{NMR}$ spectrum $\left(500 \mathrm{MHz}, \mathrm{CDCl}_{3}\right)$ of 6 .<smiles>C#CCOCCOCCOCCBr</smiles>
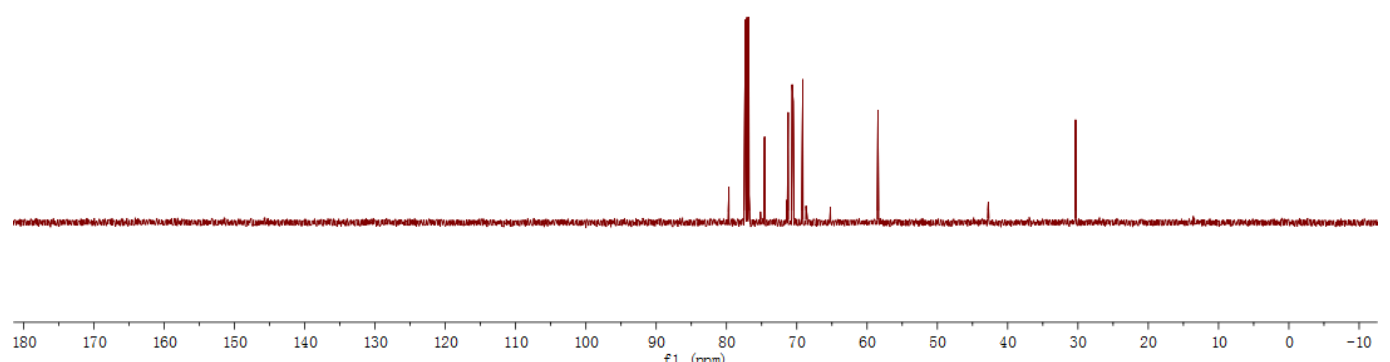

Figure S8. ${ }^{13} \mathrm{C}$ NMR spectrum $\left(125 \mathrm{MHz}, \mathrm{CDCl}_{3}\right)$ of 6. 
Compound 8: The synthesis of 7 was performed according to the previously published procedure. ${ }^{\mathrm{S} 3}$ A mixture of 6 (50.2 mg, $\left.0.2 \mathrm{mmol}\right), 7$ (74.6 mg, $\left.0.2 \mathrm{mmol}\right), \mathrm{CuI}$ (18.6 $\mathrm{mg}, 0.1 \mathrm{mmol})$ and DIPEA $(0.68 \mathrm{~mL}, 3.9 \mathrm{mmol})$ was dissolved in $5 \mathrm{~mL}$ THF. The mixture was stirred at room temperature under nitrogen atmosphere for $24 \mathrm{~h}$. The mixture was concentrated under reduced pressure. Then $20 \mathrm{~mL}$ DCM was added into the crude solid. The mixture was washed with water $(3 \times 10 \mathrm{~mL})$ and saturated $\mathrm{NaCl}$ $(3 \times 10 \mathrm{~mL})$. The organic phase was dried with $\mathrm{MgSO}_{4}$ and was concentrated under reduced pressure. The crude product was purified by flash column chromatography (eluent: petroleum ether/ ethyl acetate $=2: 1)$ to give $\mathbf{8}$ as a yellow oil $(112 \mathrm{mg}, 90 \%)$. ${ }^{1} \mathrm{H}$ NMR $\left(500 \mathrm{MHz}, \mathrm{CDCl}_{3}, \mathrm{ppm}\right): \delta 7.84(\mathrm{~s}, 1 \mathrm{H}), 5.82(\mathrm{~d}, J=9.3 \mathrm{~Hz}, 1 \mathrm{H}), 5.56-$ 5.49 (m, 2 H), 5.23 (dd, $J=10.3,3.3 \mathrm{~Hz}, 1 \mathrm{H}), 4.68$ (s, $2 \mathrm{H}), 4.26-4.05$ (m, $3 \mathrm{H}), 3.79$ (t, $J=6.3 \mathrm{~Hz}, 2 \mathrm{H}), 3.70-3.62(\mathrm{~m}, 8 \mathrm{H}), 3.45(\mathrm{t}, J=6.3 \mathrm{~Hz}, 2 \mathrm{H}), 2.20(\mathrm{~s}, 3 \mathrm{H}), 2.02(\mathrm{~s}$, $3 \mathrm{H}), 1.99$ (s, $3 \mathrm{H}), 1.87$ (s, $3 \mathrm{H}) .{ }^{13} \mathrm{C} \mathrm{NMR}\left(125 \mathrm{MHz}, \mathrm{CDCl}_{3}, \mathrm{ppm}\right): \delta$ 170.3, 170.0, 169.8, 169.0, 145.9, 121.1, 86.3, 74.0, 71.4, 71.2, 70.8, 70.6, 70.5, 69.8, 68.0, 66.9, 64.6, 61.2, 30.4, 20.7, 20.6, 20.5, 20.2. HRMS: $m / z$ calcd for $[M+\mathrm{H}]^{+}$ $\mathrm{C}_{23} \mathrm{H}_{35} \mathrm{BrN}_{3} \mathrm{O}_{12}{ }^{+}, 624.1399$, found 624.1406.
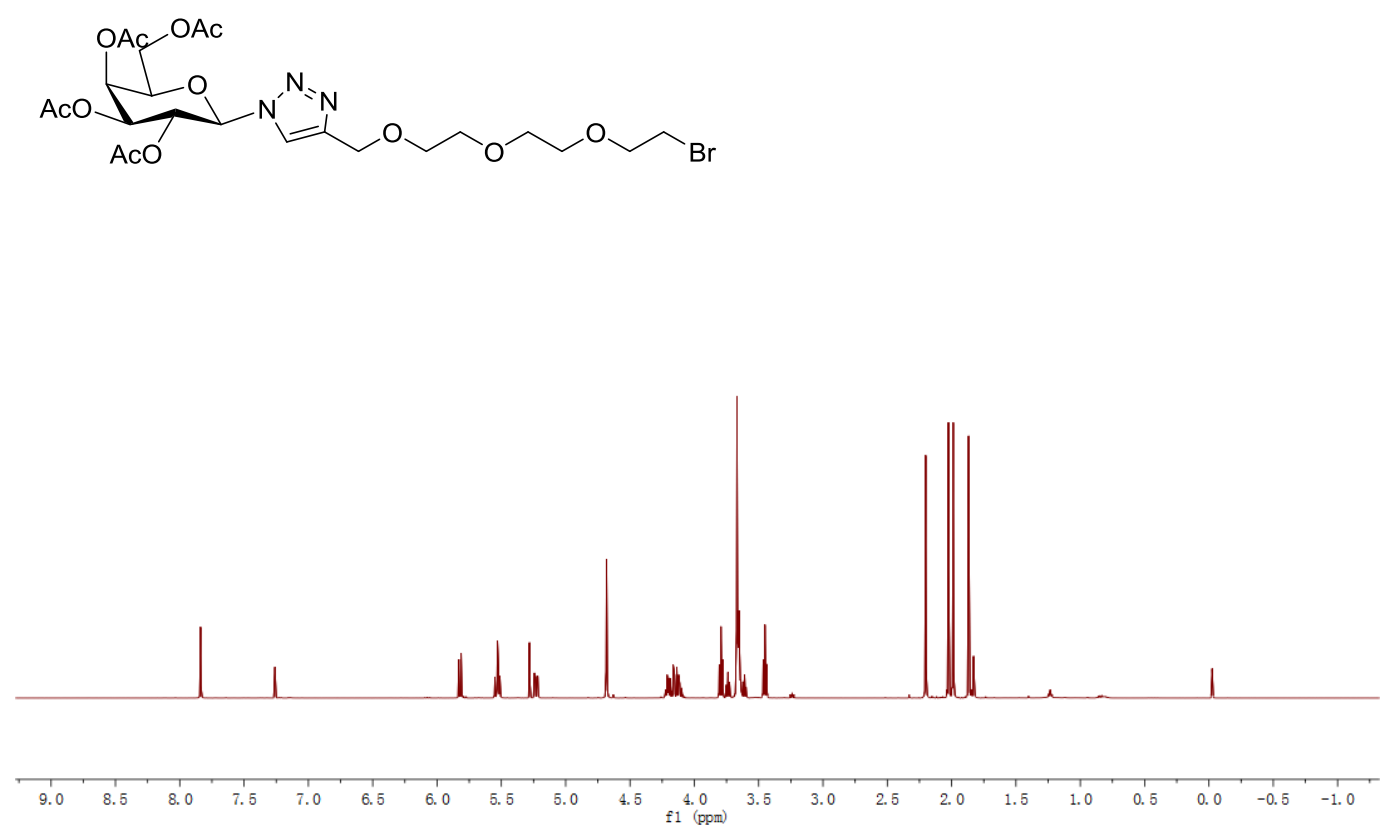

Figure S9. ${ }^{1} \mathrm{H} \mathrm{NMR}$ spectrum $\left(500 \mathrm{MHz}, \mathrm{CDCl}_{3}\right)$ of 8 . 

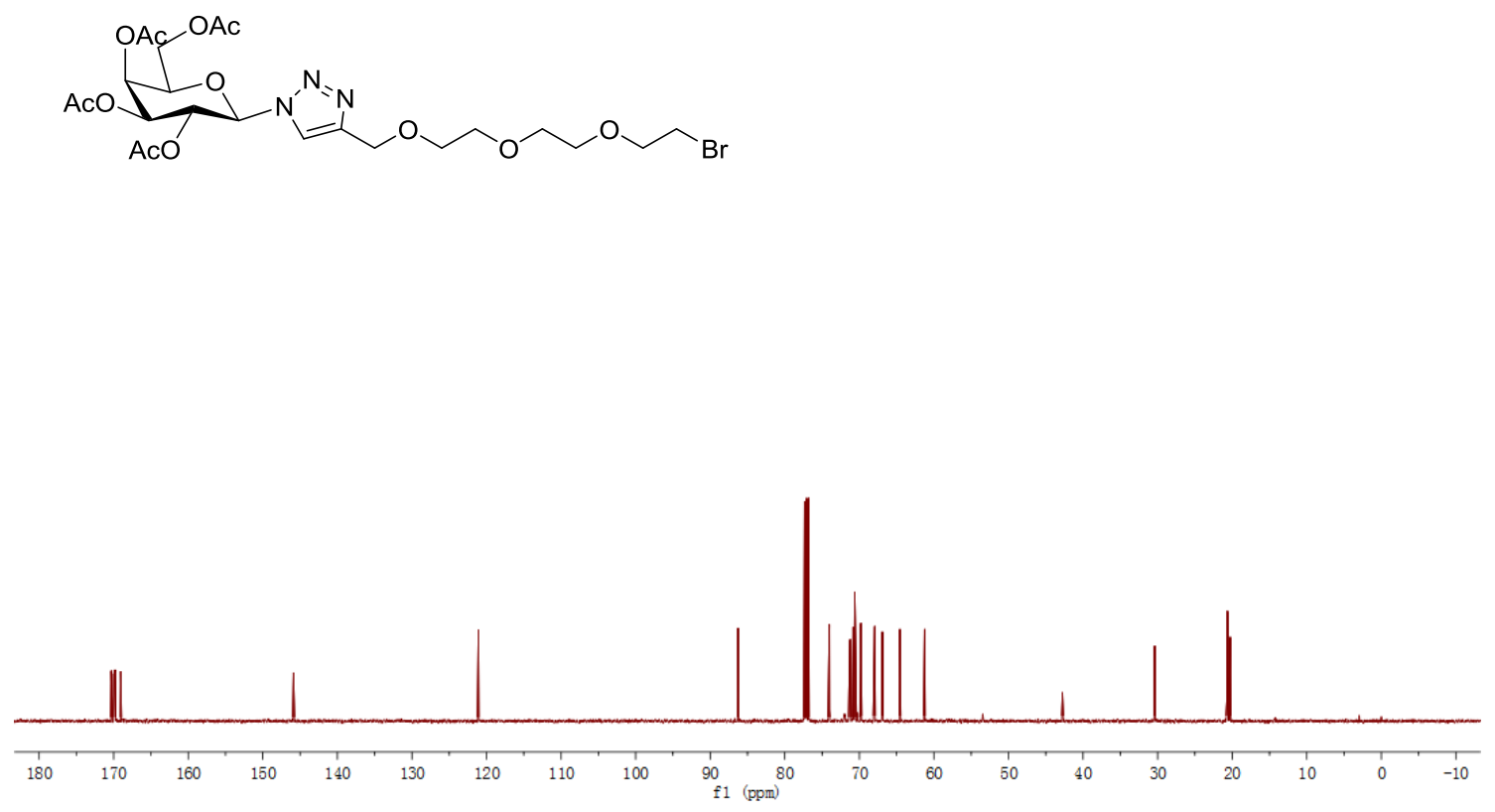

Figure S10. ${ }^{13} \mathrm{C}$ NMR spectrum (125 MHz, chloroform-d) of 8 .

Compound 9: The compound $8(62.4 \mathrm{mg}, 0.1 \mathrm{mmol})$ was dissolved in $3 \mathrm{~mL}$ pyridine. The mixture was reflux under nitrogen atmosphere for $12 \mathrm{~h}$, then concentrated under reduced pressure. The crude product was purified by flash column chromatography (eluent: petroleum ether/ ethyl acetate $=1: 4)$ to give 9 as a yellow oil $(36 \mathrm{mg}, 58 \%)$. ${ }^{1} \mathrm{H} \mathrm{NMR}\left(500 \mathrm{MHz}, \mathrm{CDCl}_{3}, \mathrm{ppm}\right): \delta 9.49(\mathrm{~d}, J=5.5 \mathrm{~Hz}, 2 \mathrm{H}), 8.43(\mathrm{t}, J=7.8 \mathrm{~Hz}, 1$ H), 8.04-7.98 (m, $2 \mathrm{H}), 7.94(\mathrm{~s}, 1 \mathrm{H}), 5.96(\mathrm{~d}, J=9.3 \mathrm{~Hz}, 1 \mathrm{H})$, 5.59-5.52 (m, $2 \mathrm{H})$, 5.29-5.23 (m, $1 \mathrm{H}), 5.23-5.17(\mathrm{~m}, 2 \mathrm{H}), 4.64(\mathrm{~s}, 2 \mathrm{H}), 4.33(\mathrm{t}, J=6.5 \mathrm{~Hz}, 1 \mathrm{H})$, 4.22-4.10 (m, $2 \mathrm{H}), 4.07-4.03(\mathrm{~m}, 2 \mathrm{H}), 3.69-3.65(\mathrm{~m}, 2 \mathrm{H}), 3.66-3.61(\mathrm{~m}, 2 \mathrm{H})$, 3.61-3.58 (m, 2 H), 3.57-3.50 (m, 2 H), 2.20 (s, 3 H), 2.03 (s, 3 H), 1.99 (s, 3 H), 1.84 (s, $3 \mathrm{H}) .{ }^{13} \mathrm{C}$ NMR $\left(125 \mathrm{MHz}, \mathrm{CDCl}_{3}, \mathrm{ppm}\right): \delta 170.3,170.0,169.8,169.1,145.9$, 145.1, 145.0, 127.8, 122.0, 86.0, 74.0, 70.8, 70.5, 70.3, 70.2, 69.7, 69.6, 68.0, 67.0, 64.2, 61.3, 61.2, 21.0, 20.7, 20.5, 20.3. HRMS: $m / z$ calcd for $[M-\mathrm{Br}]^{+} \mathrm{C}_{28} \mathrm{H}_{39} \mathrm{~N}_{4} \mathrm{O}_{12}{ }^{+}$, 623.2559, found 623.2569. 

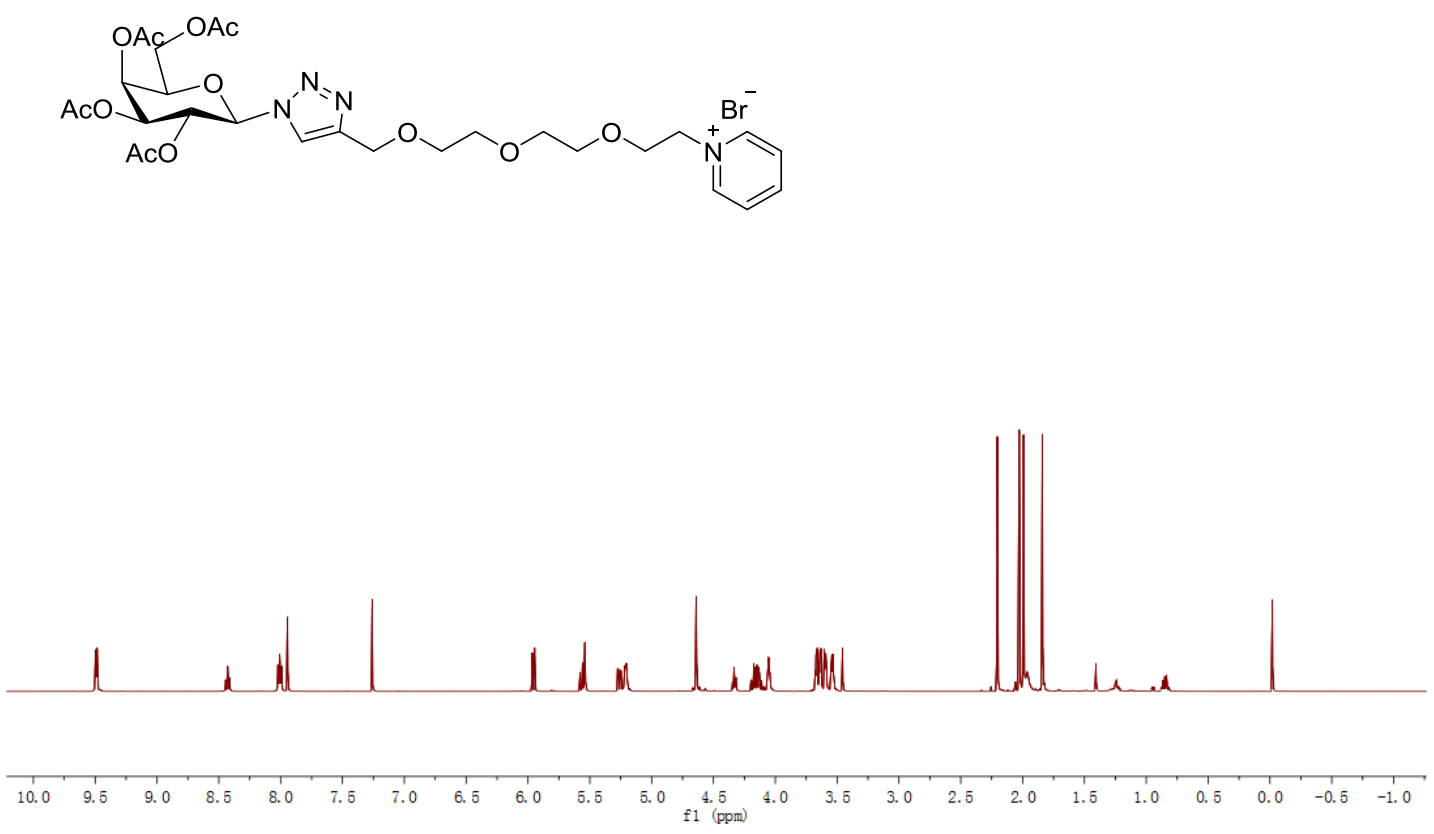

Figure S11. ${ }^{1} \mathrm{H}$ NMR spectrum $\left(500 \mathrm{MHz}, \mathrm{CDCl}_{3}\right)$ of 9.
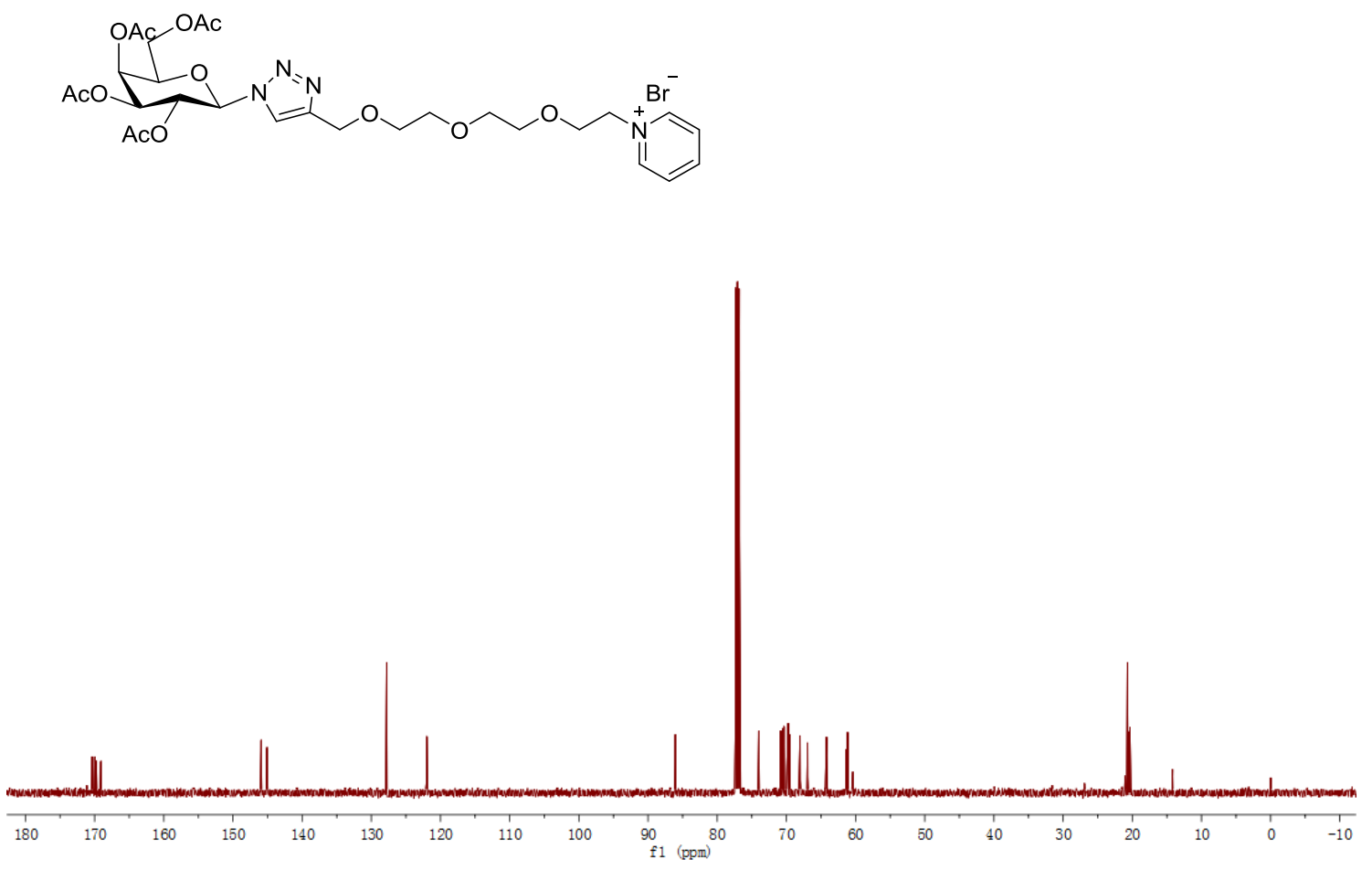

Figure S12. ${ }^{13} \mathrm{C}$ NMR spectrum $\left(125 \mathrm{MHz}, \mathrm{CDCl}_{3}\right)$ of 9.

G: $\mathrm{CH}_{3} \mathrm{ONa}(5.4 \mathrm{mg}, 0.4 \mathrm{mmol})$ was added into a solution of Compound 9 (62.3 mg, S12 
$0.1 \mathrm{mmol}$ in $5 \mathrm{~mL} \mathrm{MeOH}$ ). The mixture was stirred at room temperature for $2 \mathrm{~h}$, then neutralized by addition of ion-exchange resin (Amberlite IR $120 \mathrm{H}^{+}$) until $\mathrm{pH} 7$, filtered, and the solvent was removed under reduced pressure. The $\mathbf{G}$ was obtained as a yellow oil (43.2 mg, $95 \%) .{ }^{1} \mathrm{H}$ NMR (500 MHz, $\left.\mathrm{D}_{2} \mathrm{O}, \mathrm{ppm}\right): \delta 8.89(\mathrm{~d}, J=5.7 \mathrm{~Hz}, 2$ H), 8.63-8.56 (m, $1 \mathrm{H}), 8.35(\mathrm{~s}, 1 \mathrm{H}), 8.08(\mathrm{~s}, 2 \mathrm{H}), 5.76(\mathrm{~d}, J=8.7 \mathrm{~Hz}, 1 \mathrm{H}), 4.28(\mathrm{t}, J$ $=9.5 \mathrm{~Hz}, 1 \mathrm{H}), 4.15(\mathrm{~s}, 1 \mathrm{H}), 4.07(\mathrm{~s}, 3 \mathrm{H}), 3.94(\mathrm{~d}, J=9.8 \mathrm{~Hz}, 2 \mathrm{H}), 3.84(\mathrm{~d}, J=5.6$ $\mathrm{Hz}, 2 \mathrm{H}), 3.77-3.61(\mathrm{~m}, 10 \mathrm{H}), 3.38(\mathrm{~s}, 1 \mathrm{H}) .{ }^{13} \mathrm{C}$ NMR $\left(125 \mathrm{MHz}, \mathrm{D}_{2} \mathrm{O}, \mathrm{ppm}\right): \delta$ $146.0,144.8,144.3,128.1,124.2,88.1,78.4,73.0,69.9,69.8,69.5,69.5,69.1,68.7$, 68.6, 63.0, 61.1, 60.9. HRMS: $m / z$ calcd for $[M-\mathrm{Br}]^{+} \mathrm{C}_{20} \mathrm{H}_{31} \mathrm{~N}_{4} \mathrm{O}_{8}{ }^{+}, 455.2136$, found 455.2140 .

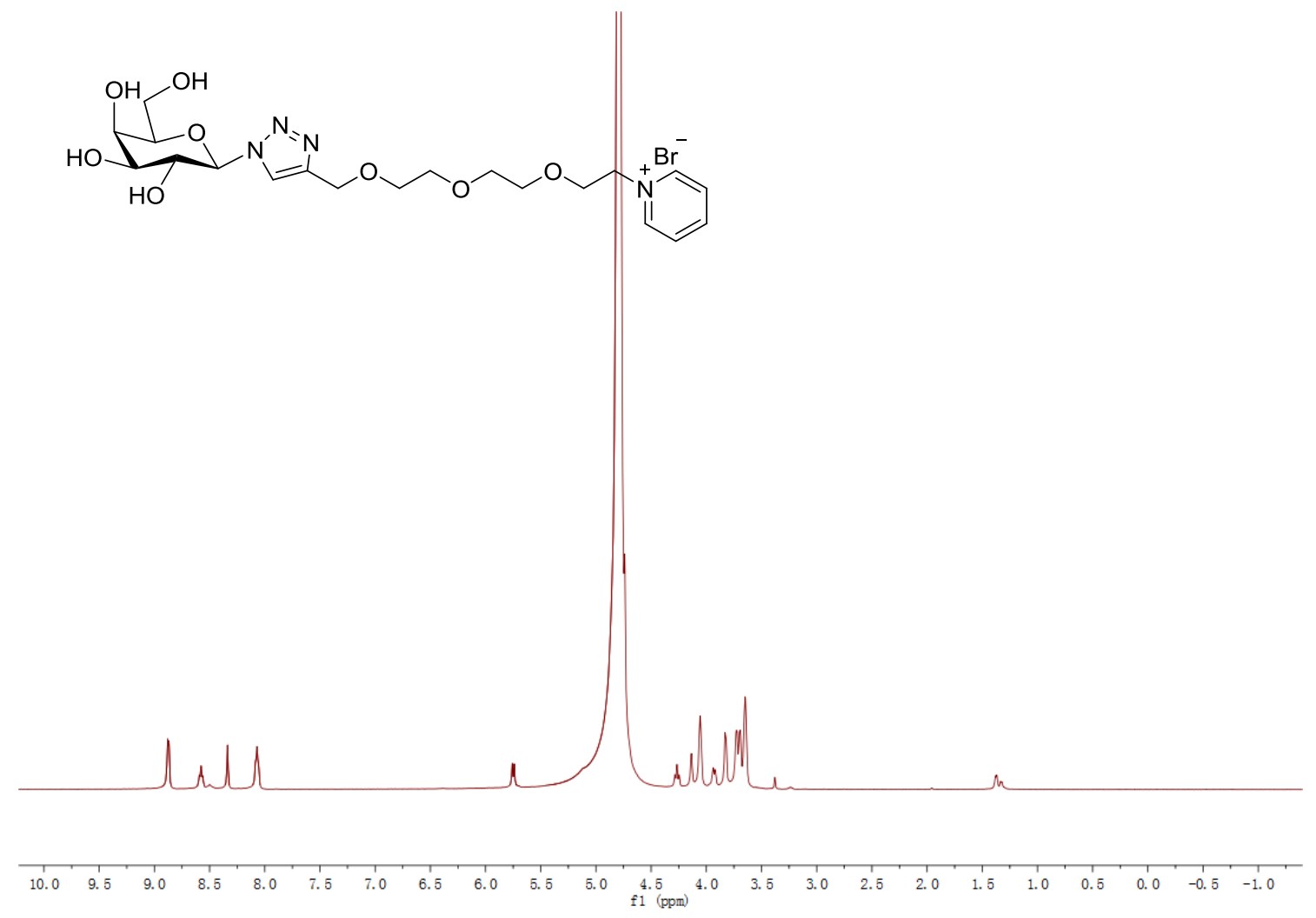

Figure S13. ${ }^{1} \mathrm{H}$ NMR spectrum $\left(500 \mathrm{MHz}, \mathrm{D}_{2} \mathrm{O}\right)$ of $\mathbf{G}$. 

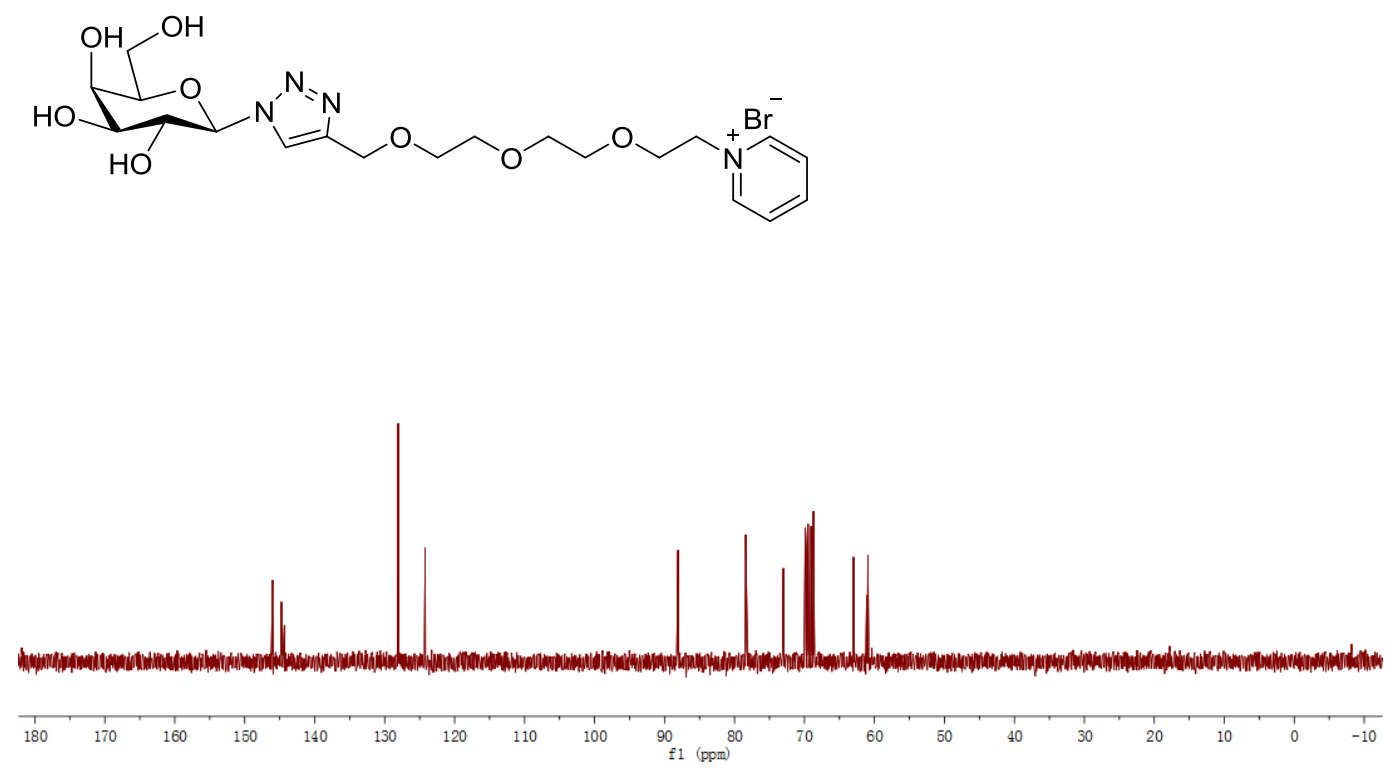

Figure S14. ${ }^{13} \mathrm{C}$ NMR spectrum $\left(125 \mathrm{MHz}, \mathrm{D}_{2} \mathrm{O}\right)$ of $\mathbf{G}$.

3. NMR and UV-Vis studies of host-guest complexation of G and TP5

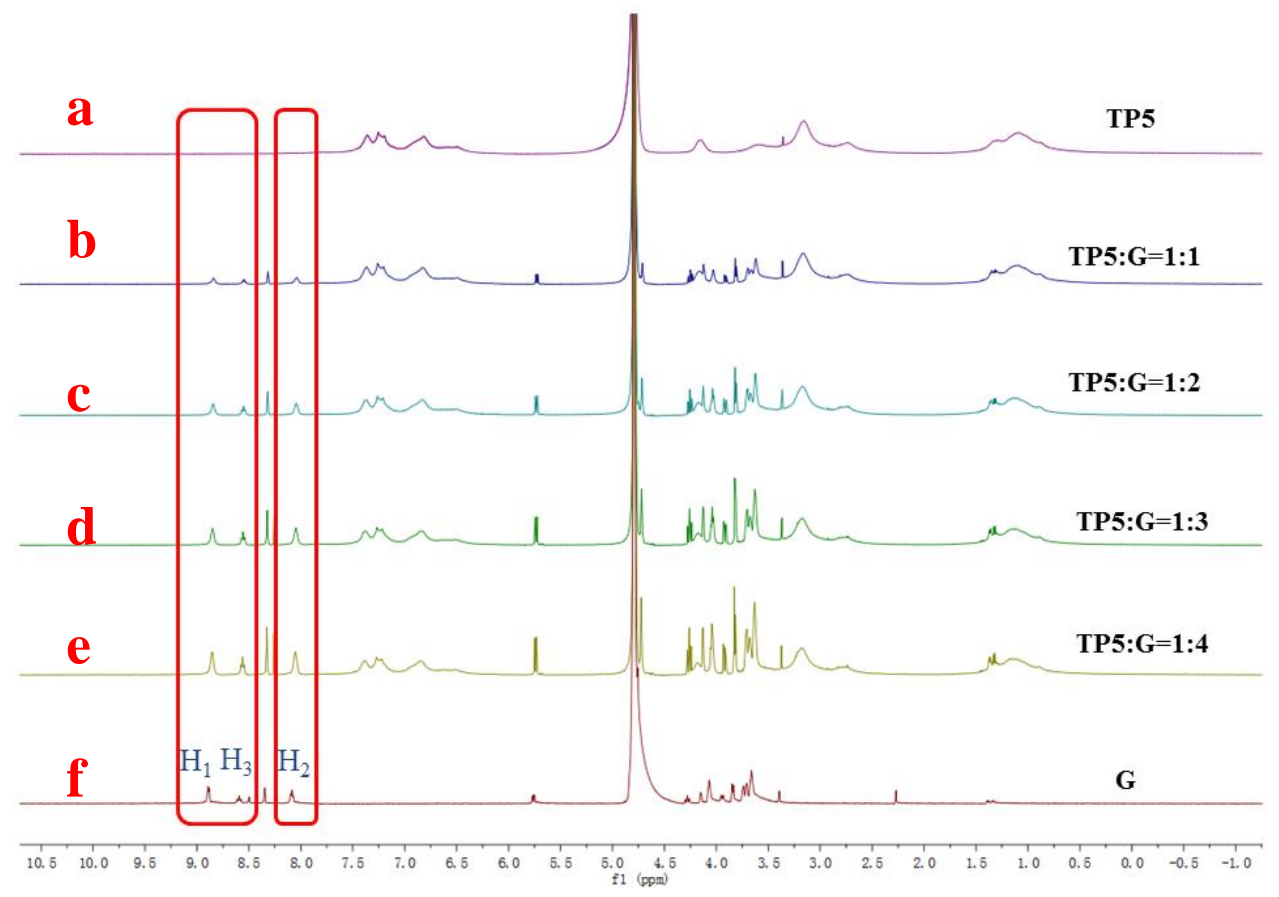

Figure S15. ${ }^{1} \mathrm{H}$ NMR spectra $\left(500 \mathrm{MHz}, \mathrm{D}_{2} \mathrm{O}, 298 \mathrm{~K}\right)$ of $\mathbf{T P 5}$ and $\mathbf{G}$ at different ratios: (a) $5 \mathrm{mM}$ TP5; (b) $5 \mathrm{mM}$ TP5 and $5 \mathrm{mM} \mathrm{G}$; (c) $5 \mathrm{mM}$ TP5 and $10 \mathrm{mM}$ G; (d) 5mM TP5 and $15 \mathrm{mM}$ G; (e) $5 \mathrm{mM}$ TP5 and $20 \mathrm{mM}$ G; (f) $5 \mathrm{mM} \mathrm{G}$. 
$\mathbf{a}$
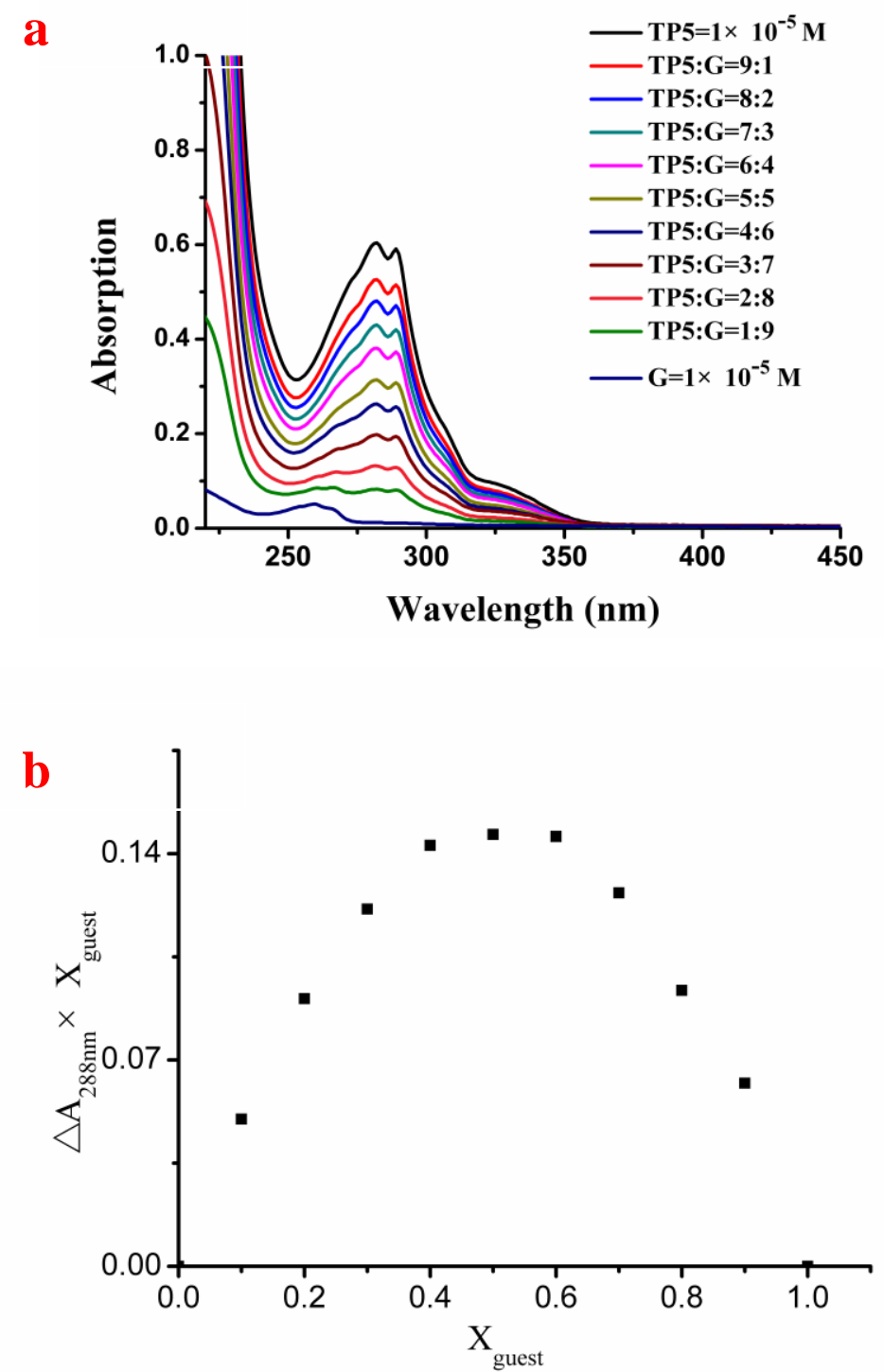

Figure S16. (a) UV-Vis absorption of the mixture of TP5 and G in water at different molar ratios while $[\mathbf{T P 5}]+[\mathbf{G}]=1.0 \times 10^{-5} \mathrm{M}$. (b) Job plot of the difference in absorption at $288 \mathrm{~nm}$ (a characteristic absorption peak of TP5) against the mole fraction of $\mathbf{G}$ at an invariant total concentration of $1.0 \times 10^{-5} \mathrm{M}$ in aqueous solution. It indicated that the complex between TP5 and $\mathbf{G}$ has 1:1 stoichiometry.

\section{Investigation of the interaction between TP5 and $G$}

To determine the association constant for the complexation between TP5 and G, fluorescence titration experiments were carried out in solutions which had a constant concentration of TP5 $\left(1 \times 10^{-5} \mathrm{M}\right)$ and varying concentrations of $\mathbf{G}$. By a non-linear 
curve-fitting method, the association constant $\left(K_{\mathrm{a}}\right)$ of TP5 $\supset \mathbf{G}$ was estimated.

The non-linear curve-fittings were based on the equation:

$\Delta \mathrm{F}=\left(\Delta \mathrm{F} \infty /[\mathrm{H}]_{0}\right)\left(0.5[\mathrm{G}]_{0}+0.5\left([\mathrm{H}]_{0}+1 / K_{\mathrm{a}}\right)-\left(0.5\left([\mathrm{G}]_{0}{ }^{2}+\left(2[\mathrm{G}]_{0}\left(1 / \mathrm{Ka}-[\mathrm{H}]_{0}\right)\right)+\left(1 / K_{\mathrm{a}}\right.\right.\right.\right.$ $\left.\left.\left.\left.+[\mathrm{H}]_{0}\right)^{2}\right)^{0.5}\right)\right) \quad($ eq. 1$)$

Where $\Delta \mathrm{F}$ is the fluorescence intensity changes at $378 \mathrm{~nm}$ at $[\mathrm{H}]_{0}, \Delta \mathrm{F} \infty$ is the fluorescence intensity changes at $378 \mathrm{~nm}$ when $\mathbf{T P 5}$ is completely complexed, $[\mathrm{G}]_{0}$ is the initial concentration of $\mathbf{G}$, and $[\mathrm{H}]_{0}$ is the fixed initial concentration of TP5. ${ }^{\mathrm{S} 4}$

$\mathbf{a}$

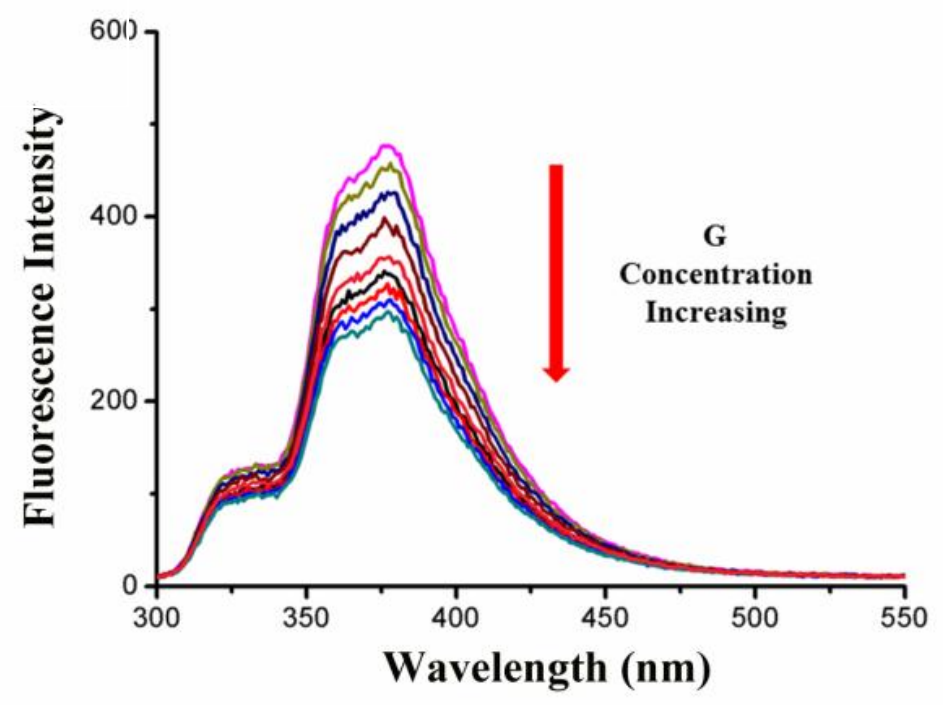

b

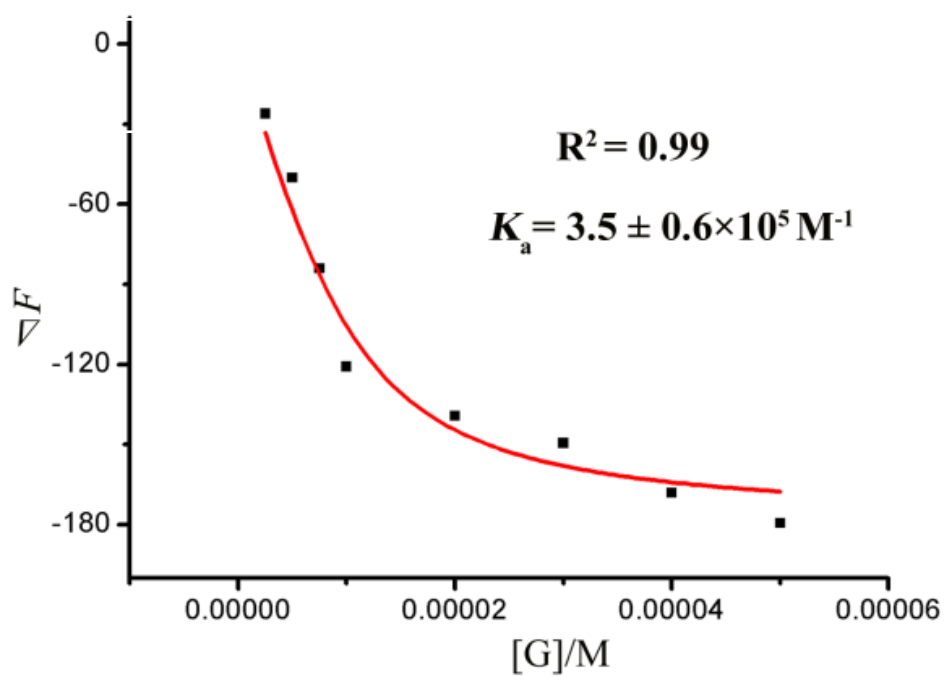

Figure S17. (a) Fluorescence spectra of TP5 $\left(1 \times 10^{-5} \mathrm{M}\right)$ upon addition of $\mathbf{G}(0-5 \times$ $10^{-5} \mathrm{M}$ ) in aqueous solution (excited at $288 \mathrm{~nm}$ ) at room temperature. Upon addition of G, emission from TP5 was quenched, indicating the formation of the TP5-G complex. (b) The fluorescence intensity changes of TP5 upon addition of G. The red 
solid line was obtained from the non-linear curve-fitting using eq. 1.

\section{The preparation and characterization of the vesicles}

$3.18 \mathrm{mg}(1 \mu \mathrm{mol})$ of $\mathbf{T P 5}$ and $0.53 \mathrm{mg}$ of $\mathbf{G}(1 \mu \mathrm{mol})$ were dissolved in $\mathrm{H}_{2} \mathrm{O}(2 \mathrm{~mL})$. The mixture was subjected to ultrasonic for 30 minutes, and then stood still overnight to obtain the vesicles, which were characterized by SEM, TEM, and DLS.

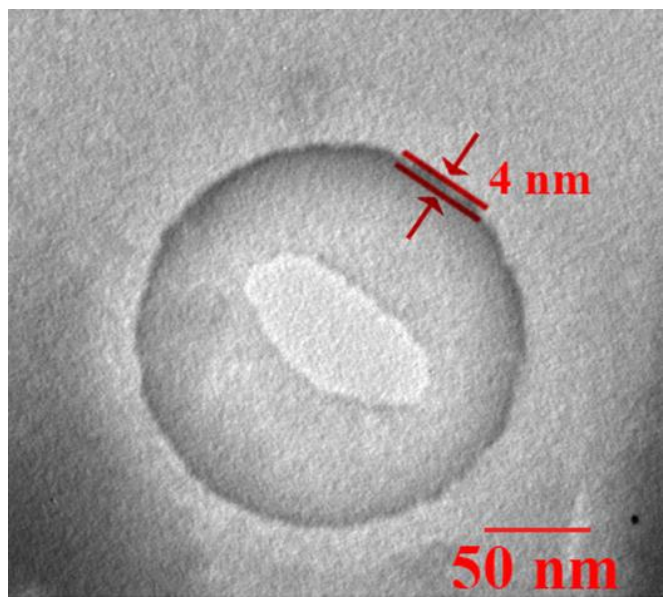

Figure S18. TEM image of TP5G. The samples were negative-stained by $1 \%$ sodium phosphotungstate. The wall thickness of the vesicles was about $4 \mathrm{~nm}$.

\section{DLS data and SEM}
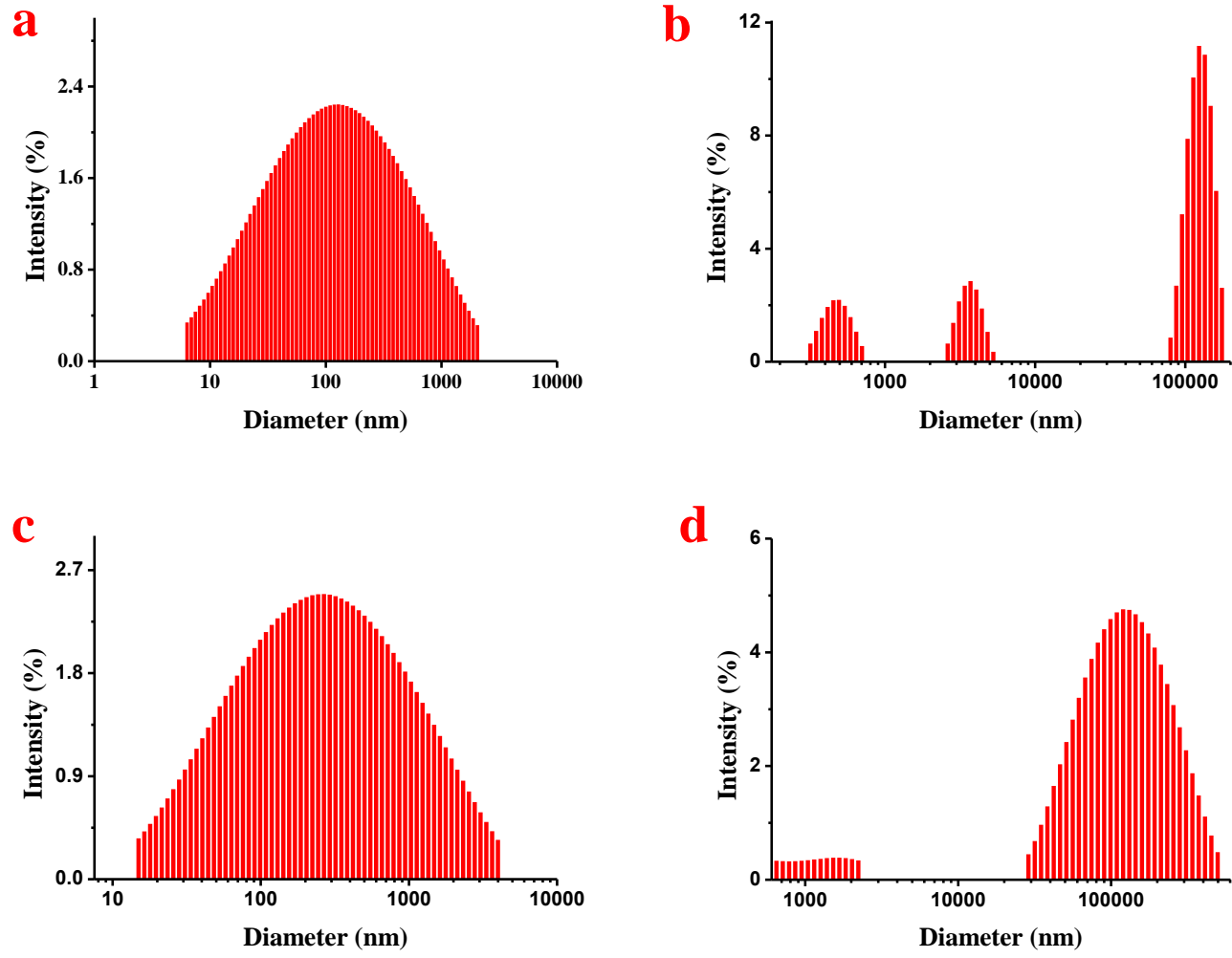
Figure S19. DLS analysis of: (a) TP5G , the diameter is about $110 \mathrm{~nm}$; (b) TP5G after adding DNA. The diameter of most particles increased to micrometer scale; (c) DOX-loaded TP5G. The diameter is about $274 \mathrm{~nm}$; (d) DOX-loaded TP5G after adding DNA, the diameter of the aggregates increased to micrometer scale. Concentration: $2 \times 10^{-4} \mathrm{M}$.
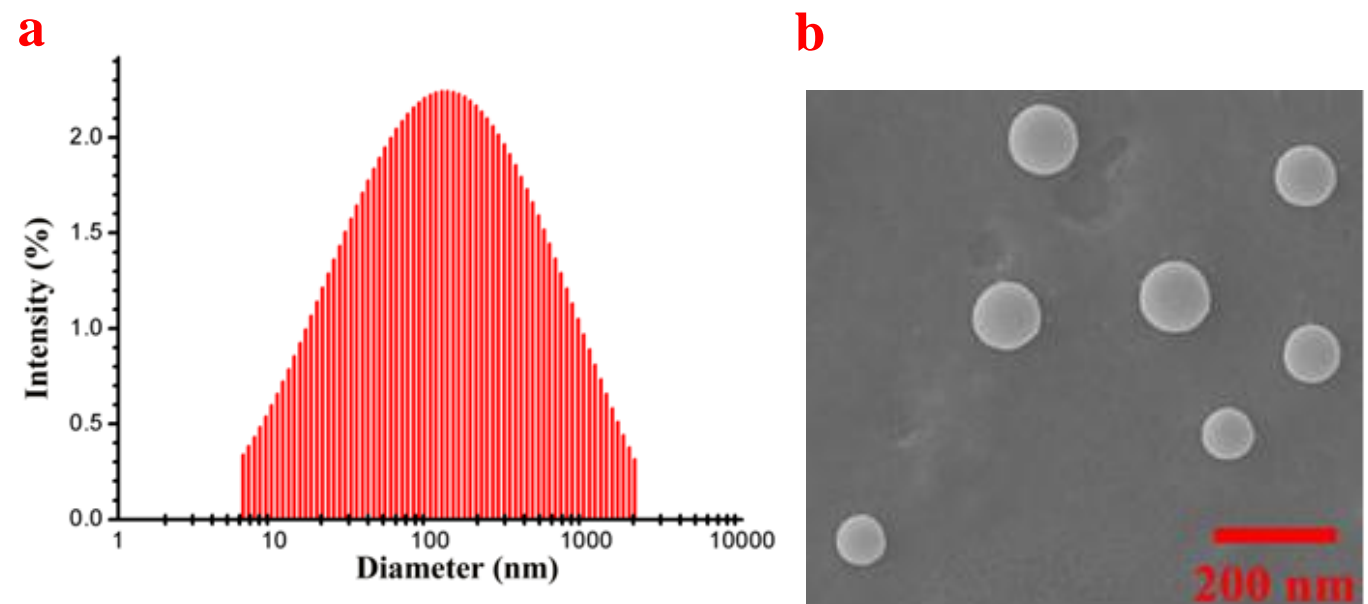

Figure S20. (a) DLS analysis of TP5 , the diameter is about $124 \mathrm{~nm}$; (b) SEM image of TP5 in aqueous solution.

\section{Critical aggregation concentration (CAC) determination of TP5}

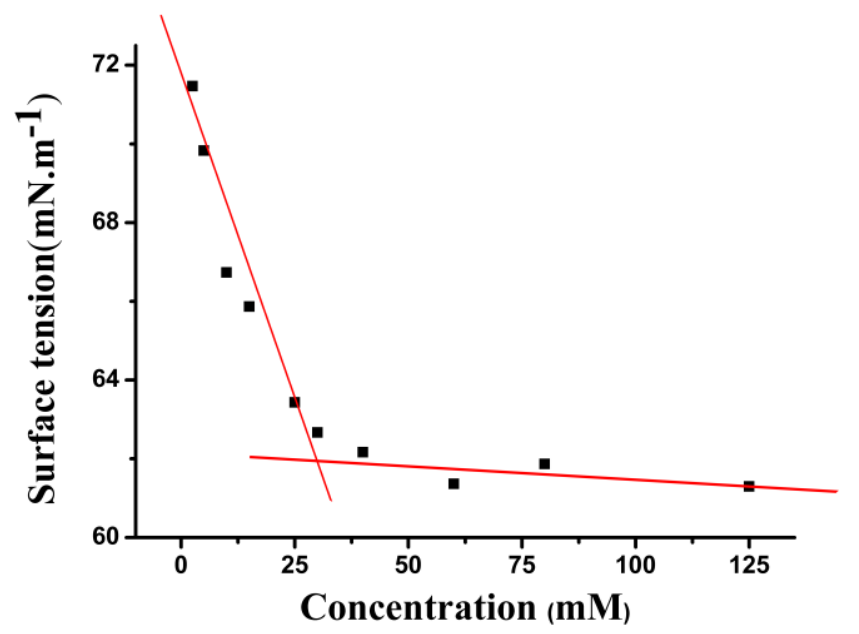

Figure S21. Plot of the surface tension of water vs. the concentration of TP5G. There are two linear segments in the plot and a sudden decrease of the slope, implying that the CAC is approximately $30 \mu \mathrm{M}$. 
8. Electrophoretic mobility, UV-Vis and FTIR studies of the interaction between TP5 and DNA.

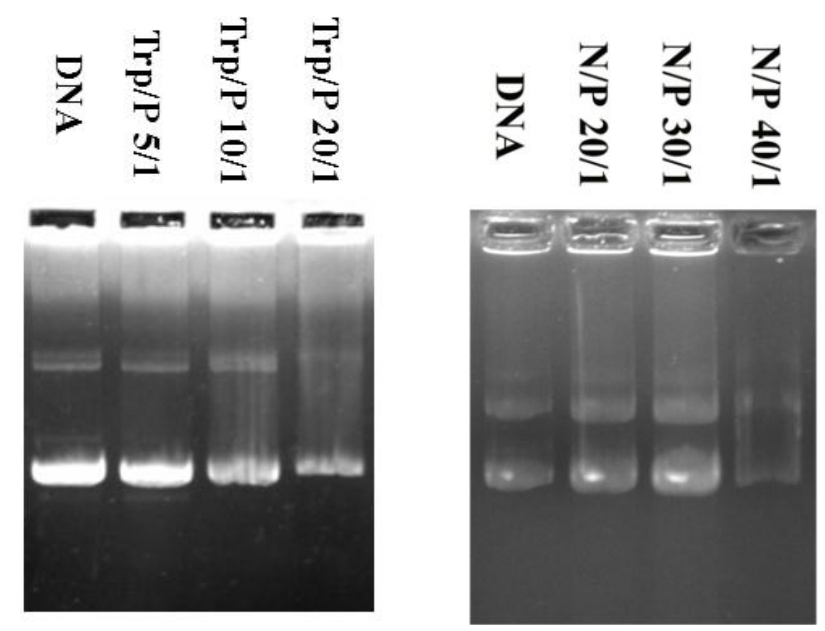

Figure S22. (a) Electrophoretic mobility of DNA in the presence of TP5 (ratios of Trp/P ranging from 0 to 20). The DNA binding ability of TP5 was assessed by electrophoresis method. pK18mobSacB plasmid DNA was used and prepared in water with a concentration of $0.8 \mathrm{mg} / \mathrm{mL}$. The complexes were electrophoresed on $1 \%(\mathrm{w} / \mathrm{v})$ agarose gel with Tris-acetate running buffer at $100 \mathrm{mV}$ for $45 \mathrm{~min}$. DNA retardation was visualized by a UV illuminator (Bio-Rad Gel Doc $\mathrm{Xr}+$ ) with ethidium bromide staining. (b) The DNA binding ability of compound $\mathbf{2}$ after acidification of the free amino groups was also assessed at the same condition.

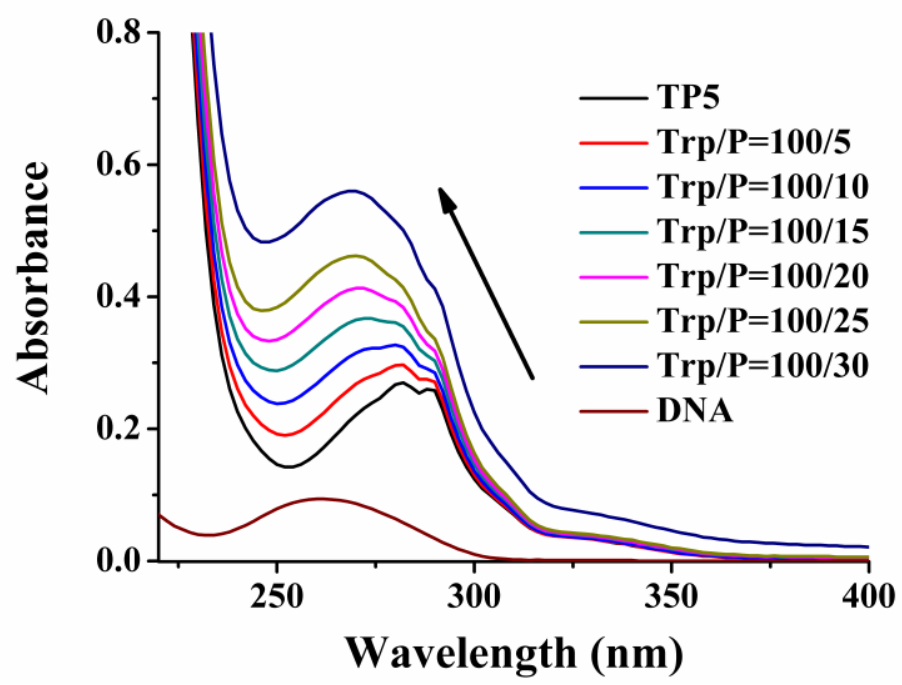

Figure S23. UV- Vis absorption of the mixtures of DNA and TP5 $\left(1 \times 10^{-5} \mathrm{M}\right)$ in water at different Trp/P ratios (Trp/P ratio: the molar ratio of Trp moieties contained in TP5 to DNA phosphate groups). 


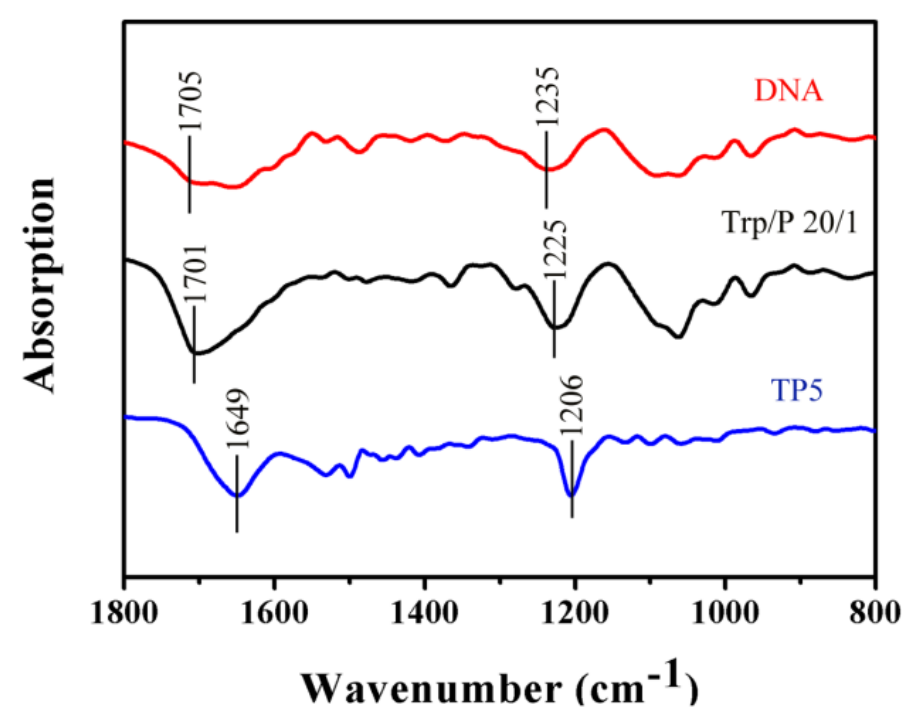

Figure S24. FTIR spectra of DNA, TRPDs, and their aggregates. Guanine bands of DNA at $1705 \mathrm{~cm}^{-1}$ shifted towards a lower frequency at $1701 \mathrm{~cm}^{-1}$ at Trp/P ratio of 20:1. Meanwhile, the band at $1235 \mathrm{~cm}^{-1}\left(\mathrm{PO}_{2}\right.$ asymmetric) shifted to $1225 \mathrm{~cm}^{-1}$.

\section{DOX loading and release}

$3.18 \mathrm{mg}(1 \mu \mathrm{mol})$ of TP5, $0.53 \mathrm{mg} \mathrm{G}(1 \mu \mathrm{mol})$, and $0.58 \mathrm{mg}$ DOX $(1 \mu \mathrm{mol})$ were dissolved in PBS (2 mL). The mixture was subjected to ultrasonic for 30 minutes, and then stood still overnight to obtain the DOX-loaded vesicles, which were purified by dialysis (molecular weight cutoff 1000) in distilled water until the water outside the dialysis bag exhibited negligible DOX fluorescence. The amount of unloaded DOX in the dialysate was quantitatively measured by UV-Vis spectrophotometry at $480 \mathrm{~nm}$. The DOX encapsulation was calculated by the following equations:

$$
\text { Encapsulation Efficiency }(\%)=\left(\mathrm{m}_{\text {DOX-loaded }} / \mathrm{m}_{\text {DOX }}\right) 100
$$

$\mathrm{m}_{\text {DOX-loaded }}$ and $\mathrm{m}_{\text {DOX }}$ are masses of DOX encapsulated in the vesicles and DOX added, respectively.

The DOX release from DOX-loaded TP5G was studied at different $\mathrm{pH}$ buffer solution. $2 \mathrm{~mL}$ of DOX-loaded TP5G vesicles in a dialysis bag were added into corresponding release medium $(18 \mathrm{~mL})$ at $37{ }^{\circ} \mathrm{C}$. At specified time intervals, the concentration of DOX was determined by UV-Vis spectrophotometry. 


\section{The study of targeting effect by flow cytometry}

HepG2 cells were cultured in 1640 medium containing $10 \%$ FBS, $1 \%$ penicillin/streptomycin (complete 1640) in $5 \% \mathrm{CO}_{2}$ at $37{ }^{\circ} \mathrm{C}$. HepG2 cells were seeded in 6-well plates $\left(1 \times 10^{5}\right.$ cells/well) and cultured in complete medium for $24 \mathrm{~h}$. The fresh medium containing $5 \mu \mathrm{M}$ free DOX or DOX-loaded TP5G were added respectively. In contrast, one group was pretreated with lactobionic acid $(2 \mathrm{mg} / \mathrm{mL})$ for $4 \mathrm{~h}$ before the incubation with DOX-loaded TP5G. After $4 \mathrm{~h}$, the cells were harvested and washed for two times with cold PBS and resuspended in $500 \mu \mathrm{L}$ PBS. Finally, cells were analyzed by a flow cytometer (Beckman Coulter Cytomics Altra).

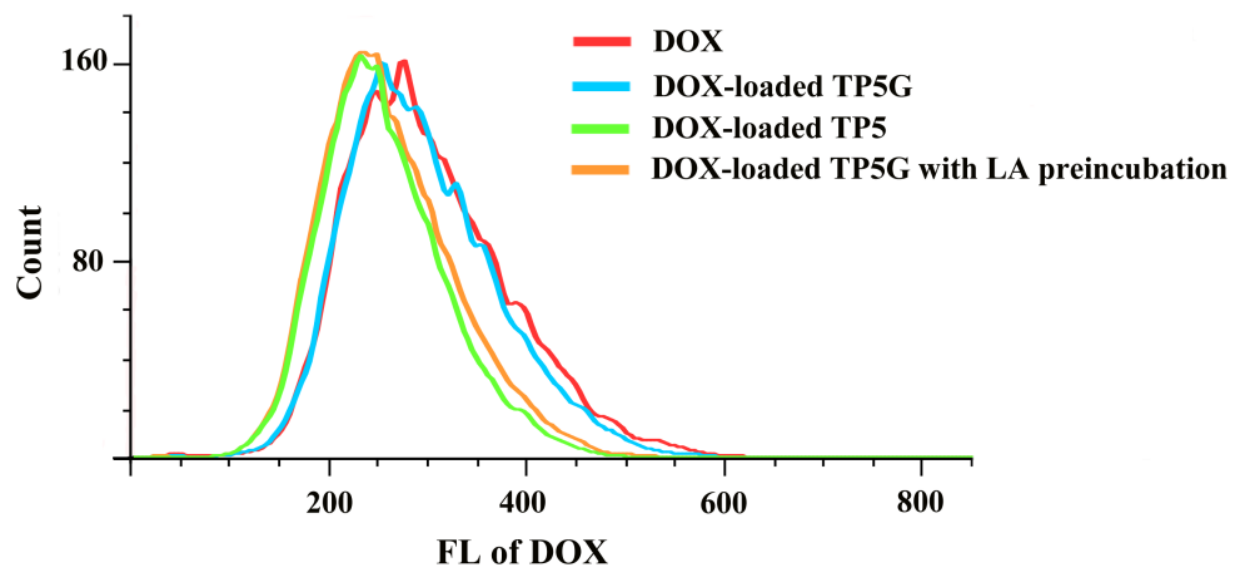

Figure S25. Flow cytometry analyses of HepG2 cells incubated in $5 \mu \mathrm{M}$ free DOX, DOX-loaded TP5, DOX-loaded TP5G, or DOX-loaded TP5G after pre-incubation with LA for $4 \mathrm{~h}$, respectively.

\section{Cytotoxicity evaluation}

Cells were cultured in 1640 medium containing $10 \%$ FBS, $1 \%$ penicillin/streptomycin (complete 1640) in $5 \% \mathrm{CO}_{2}$ at $37{ }^{\circ} \mathrm{C}$. The relative cell viability of different corresponding compounds (TP5, G, DOX, or DOX-loaded TP5G) was evaluated in vitro by MTT assay. The cells were seeded in 96-well plates at a density of $5 \times 10^{3}$ cells per well in $100 \mu \mathrm{L}$ complete 1640 and grew for $24 \mathrm{~h}$ at $37{ }^{\circ} \mathrm{C}$. Subsequently, cells were incubated with the corresponding compounds at different concentrations for $24 \mathrm{~h}, 48 \mathrm{~h}$, or $72 \mathrm{~h}$. The cells were washed and the fresh medium containing MTT was added into each plate. The cells were incubated for another $4 \mathrm{~h}$. After removing the medium containing MTT, dimethyl sulfoxide (100 $\mu \mathrm{L})$ 
was added to each well to dissolve the formazan crystals. Finally, the plate was gently shaken for $10 \mathrm{~min}$ and the absorbance at $490 \mathrm{~nm}$ was recorded with a microplate reader. HepG2 cells and HepG2/ADR cells had been used in these experiments.

$\mathbf{a}$

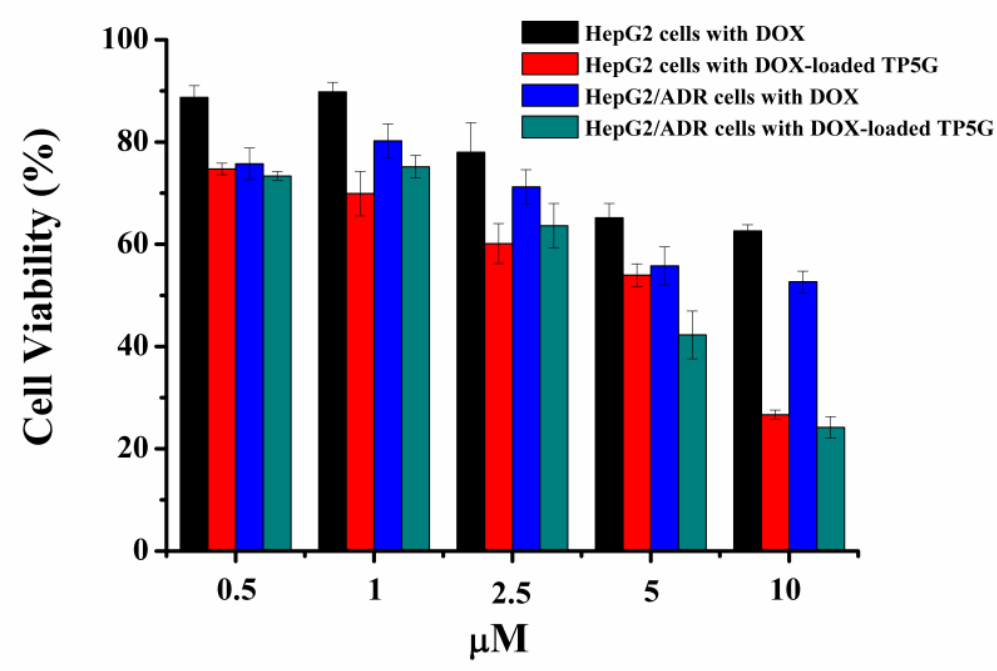

b

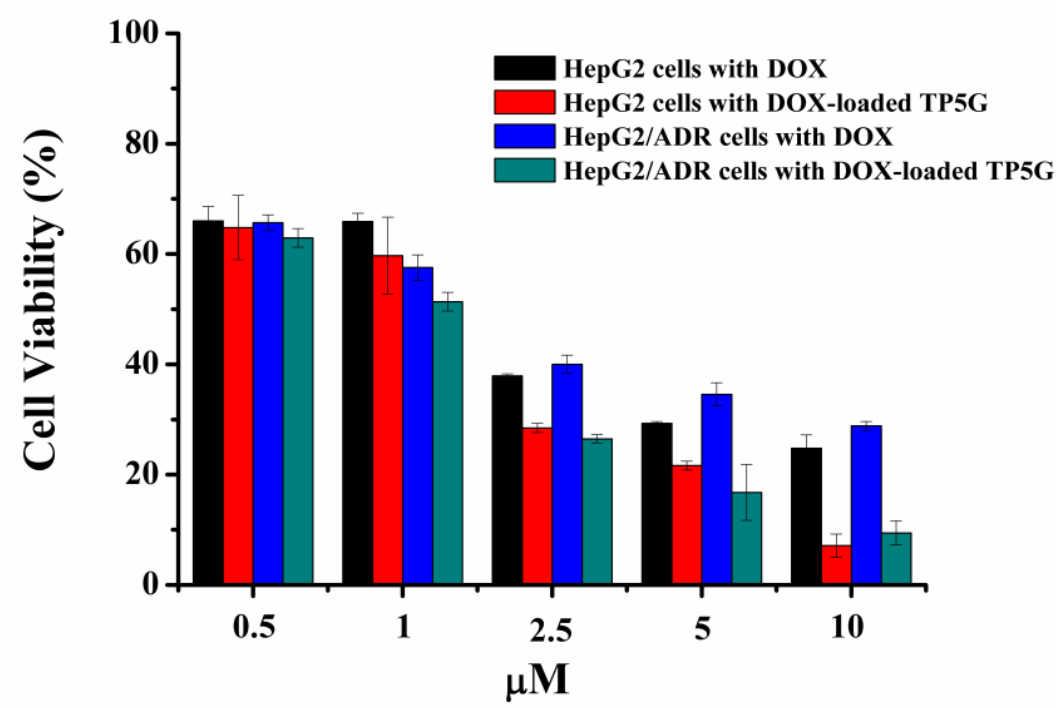

Figure S26. Cell viability of HepG2 cells and HepG2/ADR cells incubated with DOX-loaded TP5G and free DOX, respectively, for $24 \mathrm{~h}$ (a) and $48 \mathrm{~h}$ (b). 
$\mathbf{a}$

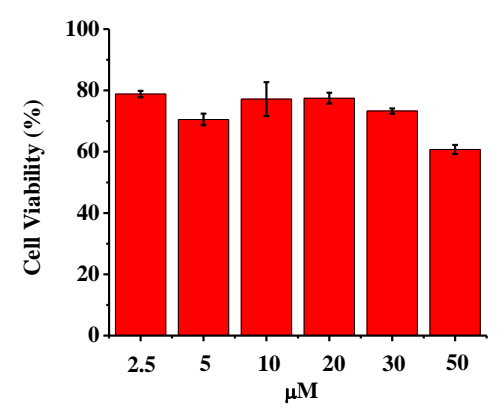

b

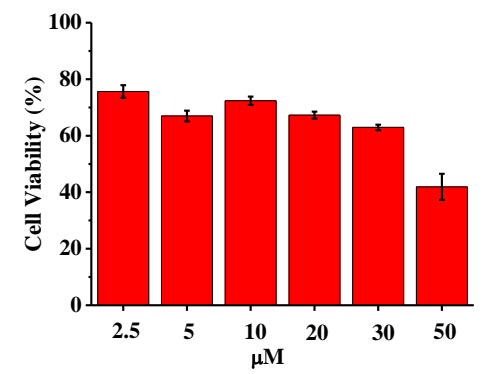

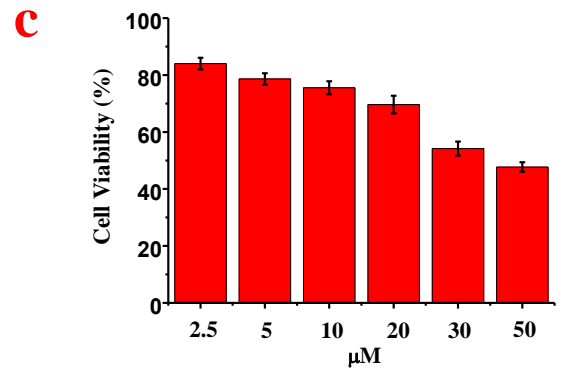

Figure S27. Cell viability of HepG2 incubated with TP5 at different concentrations for (a) $24 \mathrm{~h}$, (b) $48 \mathrm{~h}$ and (c) $72 \mathrm{~h}$.

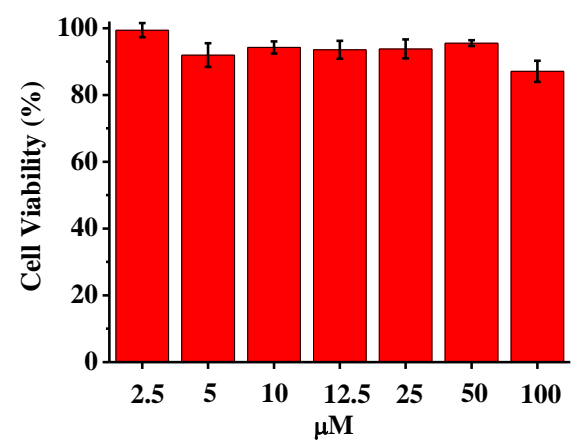

Figure S28. Cell viability of HepG2 incubated with $\mathbf{G}$ at different concentrations for $24 \mathrm{~h}$.

\section{Confocal laser scanning microscopy (CLSM)}

TP5 $(10 \mathrm{mg})$ were dissolved in DMSO $(1 \mathrm{~mL})$. Then $1 \mathrm{M} \mathrm{NaHCO}_{3}(10 \mathrm{~mL})$ was added to the solution. $1 \mathrm{~mL}$ of FITC in DMSO $(1 \mathrm{mg} / \mathrm{mL}, 1 \%$ equiv. according to the number of amine group) was dropped into the mixture and stirred at room temperature overnight in the dark. The resulting mixture was dialyzed (MWCO 1000) in $1.0 \mathrm{~L}$ of deionized water in the dark for purification. The FITC-labeled TP5 obtained was freeze-dried. HepG2 cells were seeded in $35 \mathrm{~mm}$ plastic bottomed $\mu$-dishes for $24 \mathrm{~h}$, and then the medium was replaced with a fresh one. The cells were then incubated 
with FITC- TP5 and DOX-loaded TP5G for $4 \mathrm{~h}$ at the concentration of $5 \mu \mathrm{M}$, respectively. The dishes were then washed with PBS for three times. Thereafter, the cells were stained with Hoechst 33342 for 10 min. Finally, the cells were washed with PBS and then observed under a confocal fluorescence microscope (OLYMPUS FV1000).

\section{Morphological observation by TEM}

HepG2 cells were seeded in culture flask for $24 \mathrm{~h}$, and then the medium was replaced with a fresh one. The cells were then incubated with TP5G, free DOX, DOX-loaded TP5G at $5 \mu \mathrm{M}$ and free medium, respectively. After $24 \mathrm{~h}$, the cells were harvested and washed with cold PBS. Then the cell pellets were fixed with $2.5 \%$ glutaraldehyde for $12 \mathrm{~h}$ at $4{ }^{\circ} \mathrm{C}$ and incubated with $1 \%$ osmium tetroxide $\left(\mathrm{O}_{\mathrm{S}} \mathrm{O}_{4}\right)$ for 1 $\mathrm{h}$ at $4{ }^{\circ} \mathrm{C}$. After dehydration in a graded series of ethanol and infiltration in propylene oxide, the cells embedded were used to obtain ultrathin sections with an ultramicrotome. The cell morphology was observed by TEM at $80 \mathrm{kV}$ after stained with uranyl acetate and lead citrate.
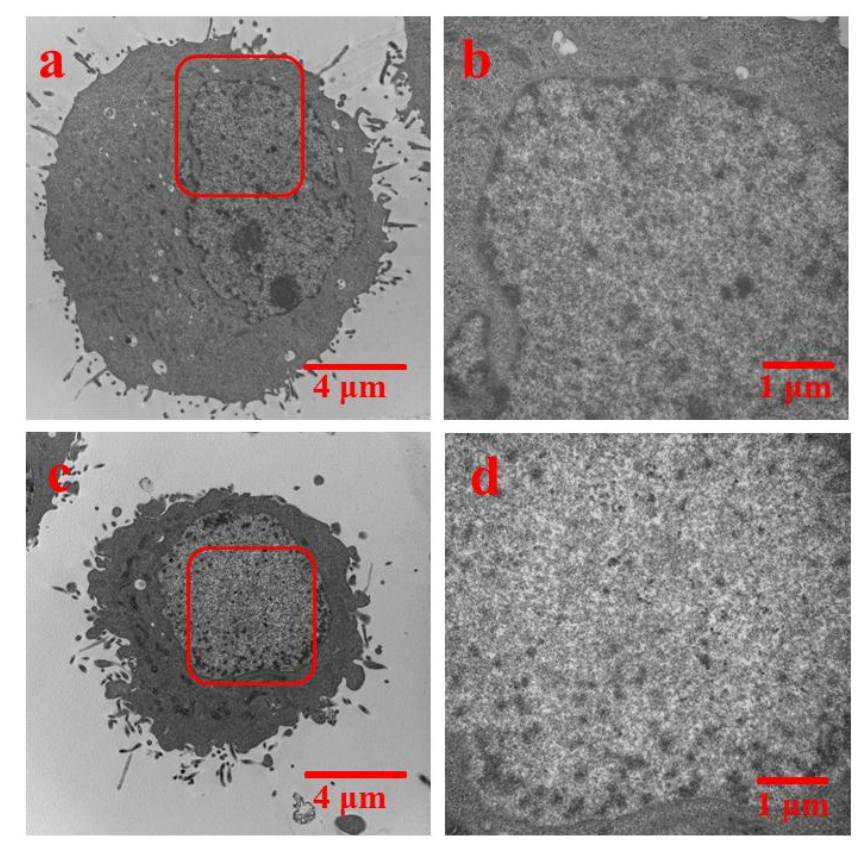

Figure S29. TEM images of HepG2 incubated with: (a) TP5G, (b) an enlarged view of the marked area in (a); (c) free DOX, (d) an enlarged view of the marked area in (c).Concentration of TP5G or DOX: $5 \mu \mathrm{M}$, incubation time: $24 \mathrm{~h}$. 


\section{References}

S1. Chang, Y. C.; Yang, K.; Wei, P.; Huang, S. S.; Pei, Y. X.; Zhao, W.; Pei, Z. C. Cationic Vesicles Based on Amphiphilic Pillar[5]arene Capped with Ferrocenium: A Redox-Responsive System for Drug/siRNA Co-Delivery. Angew. Chem. Int. Ed. 2014, 53, 13126-13130.

S2. Li, Q.; Fuks, G.; Moulin, E.; Maaloum, M.; Rawiso, M.; Kulic, I.; Foy, J. T.; Giuseppone, N. Macroscopic contraction of a gel induced by the integrated motion of light-driven molecular motors. Nature Nanotech. 2015, 10, 161-165.

S3. Su, L.; Zhao, Y.; Chen, G. S.; Jiang, M. Polymeric Vesicles Mimicking Glycocalyx (PV-Gx) for Studying Carbohydrate-protein Interactions in Solution. Polym. Chem. 2012, 3, 1560-1566.

S4. Duan, Q. P.; Cao, Y.; Li, Y.; Hu, X. Y.; Xiao, T. X.; Lin, C.; Pan, Y.; Wang, L. Y. pH-Responsive Supramolecular Vesicles Based on Water-Soluble Pillar[6]arene and Ferrocene Derivative for Drug Delivery. J. Am. Chem. Soc. 2013, 135, 10542-10549. 